\title{
Nuclear receptors: Lipid and hormone sensors with essential roles in the control of cancer development
}

\author{
Joan Font-Díaz $^{\mathrm{a}, \mathrm{b}}$, Alba Jiménez-Panizo ${ }^{\mathrm{b}, \mathrm{c}}$, Carme Caelles ${ }^{\mathrm{b}, \mathrm{d}}$, María dM Vivanco ${ }^{\mathrm{e}}$, \\ Paloma Pérez ${ }^{\mathrm{f}}$, Ana Aranda ${ }^{\mathrm{g}}$, Eva Estébanez-Perpiñá ${ }^{\mathrm{b}, \mathrm{c}}$, Antonio Castrillo ${ }^{\mathrm{g}, \mathrm{h}}$, Mercedes Ricote $^{\mathrm{i}}$, \\ Annabel F. Valledor ${ }^{\mathrm{a}, \mathrm{b}, *}$ \\ a Department of Cell Biology, Physiology and Immunology, School of Biology, University of Barcelona, Barcelona, 08028, Spain \\ ${ }^{\mathrm{b}}$ Institute of Biomedicine of the University of Barcelona (IBUB), Barcelona, 08028, Spain \\ ${ }^{\mathrm{c}}$ Department of Biochemistry and Molecular Biomedicine, School of Biology, University of Barcelona, Barcelona, 08028, Spain \\ d Department of Biochemistry and Physiology, School of Pharmacy and Food Sciences, University of Barcelona, Barcelona, 08028, Spain \\ ${ }^{\text {e }}$ CIC bioGUNE, Basque Research Technology Alliance, BRTA, Bizkaia Technology Park, Derio, 48160, Spain \\ ${ }^{\mathrm{f}}$ Instituto de Biomedicina de Valencia (IBV)-CSIC, Valencia, 46010, Spain \\ ${ }^{g}$ Instituto de Investigaciones Biomédicas "Alberto Sols", Consejo Superior de Investigaciones Científicas and Universidad Autónoma de Madrid, Madrid, 28029, Spain \\ ${ }^{\mathrm{h}}$ Unidad de Biomedicina, (Unidad Asociada al CSIC), Instituto de Investigaciones Biomédicas Alberto Sols (CSIC-UAM), Universidad de Las Palmas, Gran Canaria, \\ 35001, Spain \\ ${ }^{\mathrm{i}}$ Area of Myocardial Pathophysiology, Centro Nacional de Investigaciones Cardiovasculares (CNIC), Madrid, 28029, Spain
}

\section{A R T I C L E I N F O}

\section{Keywords:}

Nuclear receptor

Cancer

Proliferation

Apoptosis

Metastasis

\begin{abstract}
A B S T R A C T
Nuclear receptors (NRs) are a superfamily of ligand-activated transcription factors that act as biological sensors and use a combination of mechanisms to modulate positively and negatively gene expression in a spatial and temporal manner. The highly orchestrated biological actions of several NRs influence the proliferation, differentiation, and apoptosis of many different cell types. Synthetic ligands for several NRs have been the focus of extensive drug discovery efforts for cancer intervention. This review summarizes the roles in tumour growth and metastasis of several relevant NR family members, namely androgen receptor (AR), estrogen receptor (ER), glucocorticoid receptor (GR), thyroid hormone receptor (TR), retinoic acid receptors (RARs), retinoid X receptors (RXRs), peroxisome proliferator-activated receptors (PPARs), and liver X receptors (LXRs). These studies are key to develop improved therapeutic agents based on novel modes of action with reduced side effects and overcoming resistance.
\end{abstract}

\section{Introduction}

Nuclear receptors (NRs) are a superfamily of ligand-activated transcription factors that play important roles in the physiology and pathology of many biological processes, including development, metabolism, reproduction, ageing and cancer [1]. NRs constitute an integral platform that connects environmental and hormonal signals to genomic responses, which govern all kinds of cell fate decisions at the level of gene expression. As a consequence of this central role, NRs represent the target for nearly $15 \%$ of all pharmacologic drugs [2].

Progress in genomic sequencing over the years led to the identification of 48 and 49 NRs encoded by the human and mouse genomes, respectively. Members of the superfamily present a common modular structure with four main functional and structural domains, that yield a diversity of quaternary structures [3]. The NR-composing modules are a long, disordered N-terminal domain, a highly conserved DNA-binding domain (DBD), a hinge region, and a C-terminal ligand-binding domain (LBD) (Fig. 1).

The superfamily can be sub-divided in subfamilies depending on their cellular location and ligand genomic response. A group of NRs include high-affinity receptors for steroid hormones, and are typically cytoplasmic. This subfamily contains several receptors, including the androgen receptor (AR), the estrogen receptor (ER), and the glucocorticoid receptor (GR). Ligand binding allows chaperone-release and homodimerization followed by translocation into the nucleus. Once in the nucleus, the liganded receptor associates with transcriptional

\footnotetext{
* Corresponding author at: Department of Cell Biology, Physiology and Immunology, School of Biology, University of Barcelona, Barcelona, 08028, Spain.

E-mail address: afernandezvalledor@ub.edu (A.F. Valledor).
} 


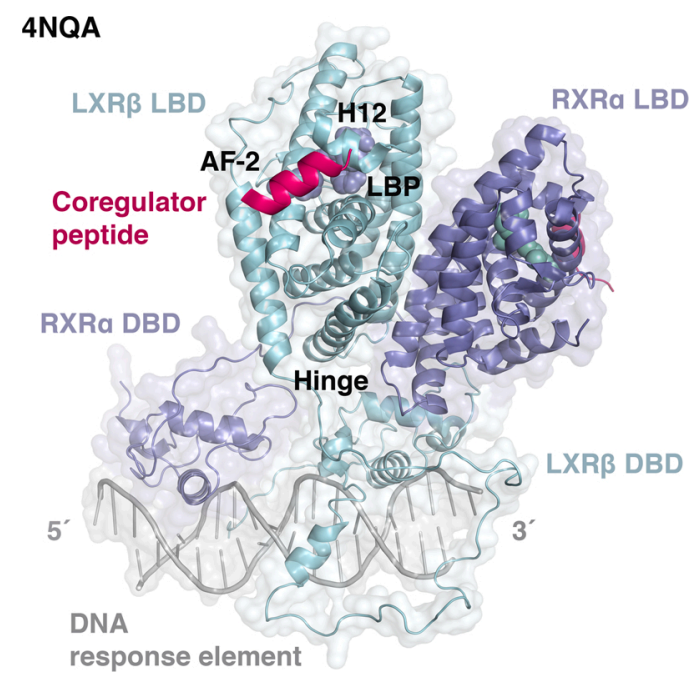

Fig. 1. NRs present a common modular structure with four main functional domains. The $\mathrm{N}$-terminal domain is highly variable and includes several distinct regulatory regions (also known as AF1 for activation function 1) (not shown). A central DBD, composed of two highly conserved zinc fingers, directs the receptor to specific consensus DNA motifs that serve as response elements. An intermediate domain known as the hinge region exhibits domain flexibility for simultaneous receptor dimerization and binding to DNA, and contains a nuclear localization signal. The $\mathrm{C}$-terminal half of the receptor harbours a large LBD, which confers the crucial property of ligand recognition and shifts the receptor to a transcriptionally active state in a specific and selective manner. The LBD also contributes to various protein-protein interactions in the subset of NRs that form heterodimers. There is also a C-terminal domain that contains an important pocket, the activating function 2 (AF-2). Within this pocket, H12 allows many NRs to interact with coactivators in a ligand-dependent manner. The image displays the quaternary organization of the $\operatorname{RXR} \alpha-\operatorname{LXR} \beta$ heterodimer. Ribbon-diagram overview of the complex including LXR $\beta$ (cyan)-RXR $\alpha$ (lila), ligands as sphere representation (cyan and lila) and coactivator peptide (fucsia) shown as an helix docked on the AF-2 pocket. The image is shown on the direction along the DNA response element ( $5^{\prime}$ to $3^{\prime}$; grey). The hinge, LBP and H12 are also labelled. The Protein Data Bank coordinates of the 4NQA structure have been used and the rendered figure has been made with Pymol (https://pymol.org/2/).

coregulators that facilitate binding to the transcriptional machinery and the modulation of target gene expression [4].

A second subfamily is composed of receptors that normally reside in the nucleus and are bound to their cognate DNA sequences even in the absence of ligand. These members are exemplified by NRs that bind dietderived ligands or intermediates of metabolic pathways, such as vitamin $D$ receptor (VDR), retinoic acid receptor (RAR), peroxisome-proliferator activated receptors (PPARs) or liver X Receptors (LXRs). Thyroid hormone receptors (TR) are also part of this subfamily. They generally form heterodimers with the retinoid X receptor (RXR) (Fig. 1) and, in the absence of ligand, interact with NR corepressor (NCoR) and/or silencing mediator for retinoid and thyroid receptors (SMRT/NCoR2), which are part of corepressor complexes associated with histone deacetylases (HDACs), thereby repressing transcription. Conformational changes upon ligand binding lead to the dissociation of corepressors and the association of the NR with coactivator complexes, which normally include proteins with histone acetyl-transferase activity that allow an open chromatin conformation to facilitate the activation of target gene expression [1].

NRs regulate transcription by several mechanisms. As mentioned above, NRs can activate target genes by binding with their DBD directly to response elements, either as homodimers or heterodimers. Ligands allosterically control the interactions of the NR with coregulator proteins (coactivators and corepressors) by influencing either the folding or the dislodging of the C-terminal helix (helix 12, H12) as part of the AF-2 pocket (Fig. 1). Interaction with coactivators promotes the recruitment of the transcriptional machinery and the remodelling of chromatin. Nevertheless, the recently solved structure of the full-length AR has provided evidence that a coregulator can bind independently of the AF-2 pocket [5]. Whether this is an exception or the rule for other NRs remains to be further investigated.

In addition, several NRs can actively repress gene expression in the presence or absence of ligand, and some of them have been reported to inhibit transcription in a ligand-dependent manner by tethering and antagonizing the activity of other transcription factors (mechanisms collectively named as transrepression). The functions of NRs can also be modulated by posttranslational modifications that include phosphorylation, ubiquitylation, and SUMOylation, among others [4].

The pivotal role of several NRs in cancer development and progression has long been acknowledged [6]. The biological actions of several NRs in the control of proliferation, differentiation, and apoptosis are indicative of the potential influence for NRs and their ligands on tumour progression (Fig. 2). Indeed, several drugs targeting NRs have been the focus of extensive drug discovery efforts for efficacious cancer interventions (Table 1). In this review, we present a summary of the roles of a selected subset of druggable NR family members with established importance in the regulation of tumour growth. This review does not include VDR, which has been extensively covered in a separate review from this series [7].

\section{Androgen receptor as a therapeutic target in prostate cancer}

Androgens are steroid hormones required for the development of the male reproductive system and secondary sexual characteristics. AR (NR3C4) is the main transcription factor that mediates the biological effects of androgens. In addition to the male reproductive system, AR is expressed in several other tissues such as bone, muscle, adipose tissue, brain and hematopoietic cells. The endogenous ligands that bind AR are $5 \alpha$-dihydrotestosterone (DHT) and testosterone [8]. In prostate cells, testosterone may act directly on AR or be irreversibly converted to DHT by $5 \alpha$-reductase.

Several pathological situations associated with AR and androgens have been described, including androgen insensitivity syndrome and prostate cancer, among others [8]. In this section, we will focus on the roles of AR in prostate cancer.

The androgen signalling axis plays a pivotal role in the pathogenesis of prostate cancer. As AR regulates multiple cellular events, including proliferation, apoptosis, migration, invasion, and differentiation, this receptor has been associated to all stages of this type of cancer [8]. In this regard, AR is both expressed in primary prostate cancer and in tumour metastasis, and DHT promotes the growth and survival of prostate cells. The heterogeneous nature of prostate cancer suggests that the predisposition to this disease may involve multiple genes and variable phenotypic expression of AR-regulated genes. Expression profiling identified indeed over 200 androgen-responsive genes involved in prostate cell proliferation, communication, differentiation, and cancer progression [9]. Of note, chromosomal rearrangements fusing the androgen-regulated gene coding for transmembrane protease serine 2 (TMPRSS2) to the ETS transcription factor ERG occur in approximately $50 \%$ of prostate cancers. The up-regulation of the TMPRSS2:ERG fusion by AR plays an early role in prostate cancer development and progression $[10,11]$. In addition, several growth-promoting and survival pathways interact with AR signalling during the development of prostate cancer. These include the PI3K/AKT/mTOR pathway and DNA repair pathways [12].

The gonadal depletion of androgens has been widely used to treat the disease; however, the progression towards more aggressive forms of the disease due to the restoration of AR signalling or intratumoral steroidogenesis sparked the development of AR protein-targeted therapies to inhibit its hormone binding. In concrete, a battery of drugs that block androgen production to inhibit the AR axis or inhibitors that directly 


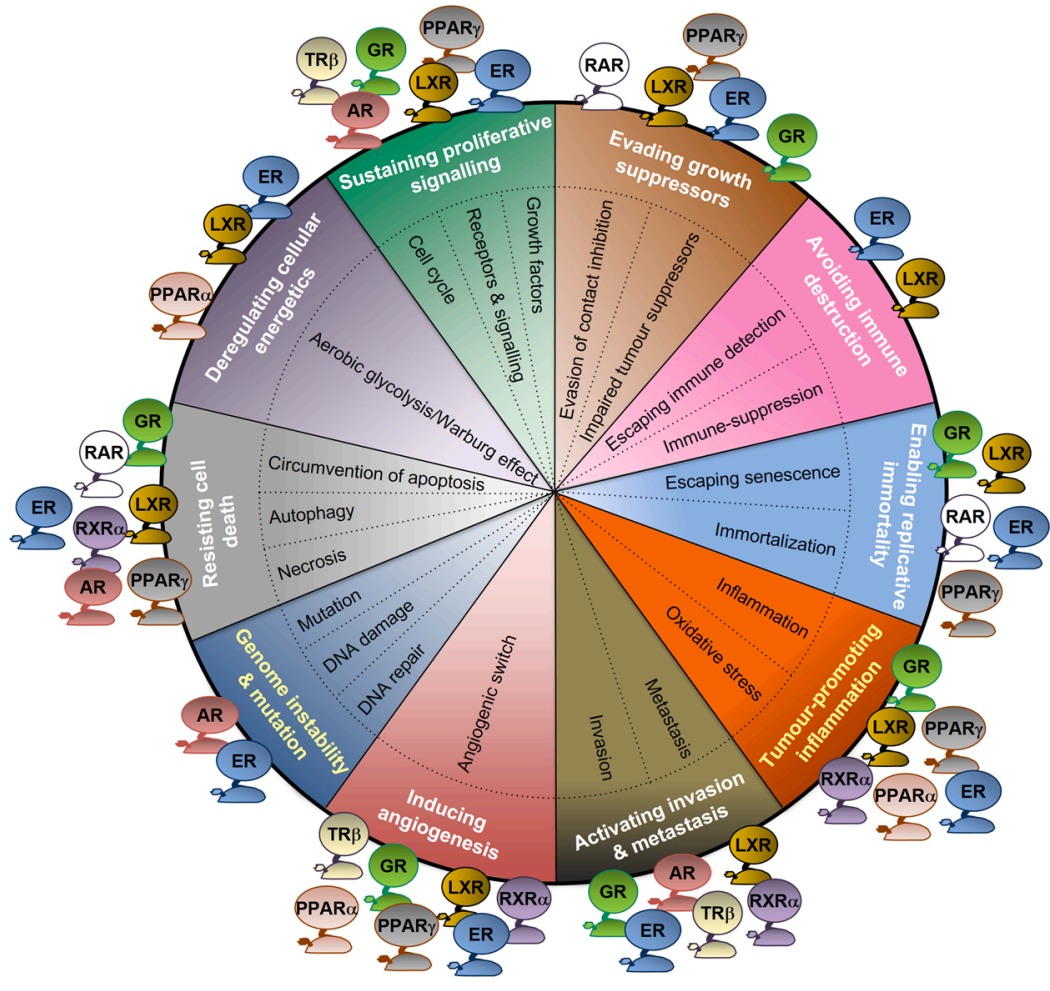

Fig. 2. Ligands that modulate NR function have the ability to impact several hallmarks and enabling characteristics of cancer. In an attempt to rationalize the complexity of biological processes leading to cancer, Hanahan and Weinberg [259] proposed a framework depicting several biological capabilities (hallmarks) acquired during tumour development (white titles): sustaining proliferative signalling, evading growth suppressors, resisting cell death, enabling replicative immortality, inducing angiogenesis, activating invasion and metastasis, reprogramming of energy metabolism and evading immune destruction. Underlying these hallmarks are two enabling characteristics (yellow titles): genome instability and tumour-promoting inflammation, which are crucial to the acquisition of the hallmark capabilities. Ligands for several NRs exert anti-tumoral effects by antagonizing the acquisition of hallmarks or the presence of enabling characteristics; the implicated NRs are indicated in each section. Image adapted from https://chat.lionproject.net/hallmarks. compete for DHT binding result in the inhibition of AR activity and have proven to be effective to delay prostate cancer growth and progression [12].

Several anti-androgens have been developed that differ in their chemical structure and exhibit different efficacy and safety profiles. For instance, flutamide, nilutamide and bicalutamide were primarily developed to be used in combination with chemical or surgical castration to provide combined androgen blockade. Later on, clinical trials in patients with metastatic, castration resistant prostate cancer showed significant survival benefits by the usage of enzalutamide. Improved antiandrogens such as apalutamide and darolutamide have proven to be efficacious as well to overcome resistance caused by other antiandrogens (i.e. bicalutamide) (Table 1) [12].

However, targeting the AR ligand-binding-pocket (LBP) remains to be prone for the drug-acquired appearance of mutations that render these compounds ineffective within $2-5$ years. Thus, the effect of this type of LBP-centred treatment remains transient, as, almost universally, patients relapse after developing a castration-resistant form of the disease (metastatic castration-resistant prostate cancer, mCRPC) that is usually due to increased levels of AR expression or point-mutations [13, 14]. Most of these molecular mechanisms of resistance cause the AR to recognize anti-androgens as if they were agonists, which is associated with cancer progression to lethal stages of the disease. Several mutations inside the LBP (e.g. T878A, W742 L, F877 L) have been found in patients that contribute to the acquisition of agonistic properties of anti-androgens $[13,14]$. Moreover, the interplay between AR and the PI3K-AKT-mTOR pathway contributes to enhance drug-resistance, raising the interest for testing the efficacy of PI3K inhibitors to overcome mCRPC [15].

The synthesis of truncated AR splice variants devoid of the receptor LBD has emerged as an additional mechanism in mCRPC [16]. The discovery of AR variants without the canonical druggable hormone-binding domain has both posed a challenge but most importantly contributed in exploring non-LBD centred pharmacological strategies. However, the exact role of these variants in cancer is still not fully understood. It is not clear whether the loss of different C-terminal parts of the AR protein, including the bipartite nuclear localization signal in the hinge region, deeply affect their nuclear localization and ligand-independent functions or whether the full length AR is still the driving transcription factor in prostate cancer. Indeed, studies still point to the fact that AR truncated variants require the full length $A R$ as partner of heterodimerization to exert their functions in cancer. The molecular profiling of AR variants, mainly AR-V7, in liquid biopsies seems to be an emerging field to monitor the treatment response [17].

A new class of compounds has emerged over the last years with the capacity to induce AR protein degradation (AR degraders). In particular, ARV-110, which has been developed using the Proteolysis-Targeting Chimera (PROTAC) technology [18], is a selective AR degrader capable of potently reducing AR signaling. Using patient-derived xenograft models, ARV-110 inhibited the growth of tumors that are resistant to enzalutamide [19]. In addition, data from an ongoing clinical trial shows some efficacy of ARV-110 in patients with mCRPC (Table 1) [20].

A potent steroidal multi-target agent named galeterone has been developed as well, which exhibits three different activities, it inhibits cytochrome P450 family member 17A1 (CYP17A1), it antagonizes AR, and it acts as an AR degrader [21]. The compound is currently under investigation and it has been proposed to potentially control full length AR as well as truncated variants such as AR-V7 [22]. Recent studies have shown its anti-tumor activity in CRPC patients (Table 1) [23]. It is important to point out that galeterone may be also effective in patients with the point mutation T878A in the AR LBD [24].

Recently, GR has also received significant traction as the NR driving prostate cancer resistance. Indeed, enhanced GR expression was identified as a common feature in the development of resistance to antiandrogens [25]. As GR and AR can recognize identical regulatory sequences, the functional substitution of GR over AR in prostate cancer cells resulted in the regulation of a subset of AR targets, which was sufficient to preserve the resistant phenotype $[25,26]$. Treatment with the GR ligand dexamethasone was sufficient to induce enzaludamide-resistance whereas GR blockade restored sensitivity. Also, AR blockade led to high levels of GR in a subset of prostate cancer cells due to the lack of AR-mediated feedback repression of GR. These 
Table 1

Several drugs targeting NRs are used to treat different types of cancer. Examples of compounds that target NR activity/stability and are either currently used in the clinics or being tested in clinical trials for the therapeutic treatment of cancer. CLL, chronic lymphocytic leukemia; HER2, erb-b2 receptor tyrosine kinase 2; HL, Hodgkin's lymphoma; $\mathrm{HR}^{+}$, hormone-receptor-positive; MM, multiple myeloma; MR, mineralocorticoid receptor; NHL, non-Hodgkin's lymphoma.

\begin{tabular}{|c|c|c|c|}
\hline Ligand & NR & Action & To treat \\
\hline Enzalutamide & $\mathrm{AR}$ & Antagonist & $\begin{array}{l}\text { Metastatic and non-metastatic } \\
\text { CRPC }\end{array}$ \\
\hline Darolutamide & $\mathrm{AR}$ & Antagonist & Non-metastatic CRPC \\
\hline Apalutamide & $\mathrm{AR}$ & Antagonist & Non-metastatic CRPC \\
\hline Abiraterone & $\mathrm{AR}$ & Antagonist & mCRPC \\
\hline Galeterone & $\mathrm{AR}$ & Antagonist & Clinical trial: mCRPC \\
\hline ARV-110 & $\mathrm{AR}$ & $\begin{array}{l}\text { AR } \\
\text { degrader }\end{array}$ & Clinical trial: mCRPC \\
\hline Tamoxifen & ER & SERM & $\begin{array}{l}\text { Early- and advanced-stage } \mathrm{HR}^{+} \\
\text {breast cancer, neoadjuvant } \\
\text { therapy; to lower the risk of } \\
\text { breast cancer in women at high } \\
\text { risk }\end{array}$ \\
\hline Toremifene & ER & SERM & $\begin{array}{l}\text { Postmenopausal women with } \\
\text { metastatic, } \mathrm{HR}^{+} \text {breast cancer }\end{array}$ \\
\hline Raloxifene & ER & SERM & $\begin{array}{l}\text { To lower the risk of breast cancer } \\
\text { in high-risk postmenopausal } \\
\text { women }\end{array}$ \\
\hline Fulvestrant & ER & SERD & $\begin{array}{l}\text { Postmenopausal women, } \\
\text { advanced-stage breast cancer or } \\
\text { after tamoxifen failure }\end{array}$ \\
\hline Dexamethasone & GR & Agonist & $\begin{array}{l}\text { Lymphoid cancers (ALL, CLL, } \\
\text { MM, HL and NHL); palliative use } \\
\text { in several cancers (breast, lung, } \\
\text { bladder) }\end{array}$ \\
\hline Prednisolone & $\begin{array}{l}\text { GR/ } \\
\text { MR }\end{array}$ & Agonist & $\begin{array}{l}\text { Lymphoid cancers (ALL, CLL, } \\
\text { MM, HL, and NHL; palliative use } \\
\text { in several cancers }\end{array}$ \\
\hline Methylprednisolone & GR & Agonist & $\begin{array}{l}\text { Coadjuvant for hematopoietic } \\
\text { and non-hematopoietic cancers }\end{array}$ \\
\hline Hydrocortisone & GR & Agonist & Palliative use in several cancers \\
\hline $\begin{array}{l}\text { Recalorilant/ } \\
\text { CORT125134 }\end{array}$ & GR & SEGRAM & Cinical trials: solid tumors \\
\hline ORIC-101 & GR & SEGRAM & $\begin{array}{l}\text { Clinical trials: solid tumors/ } \\
\text { prostate cancer }\end{array}$ \\
\hline ATRA & RAR & Agonist & $\begin{array}{l}\text { APL; Clinical trials: NSCLC, } \mathrm{HR}^{+} / \\
\text {HER2 }{ }^{-} \text {early breast carcinoma, } \\
\text { metastatic kidney cancer, } \\
\text { melanoma, neuroblastoma, } \\
\text { advanced adenoid cystic } \\
\text { carcinoma }\end{array}$ \\
\hline Tamibarotene & RAR & Agonist & $\begin{array}{l}\text { Recurrent (ATRA-resistant) APL; } \\
\text { Clinical trial: AML }\end{array}$ \\
\hline NRX195183 & RAR & Agonist & $\begin{array}{l}\text { Clinical trial: relapsed or } \\
\text { refractory APL }\end{array}$ \\
\hline Fenretinide & RAR & Agonist & $\begin{array}{l}\text { Clinical trial: adult giant cell } \\
\text { glioblastoma }\end{array}$ \\
\hline $\begin{array}{l}\text { Bexarotene/ } \\
\text { Targretin }\end{array}$ & RXR & Agonist & $\begin{array}{l}\text { CTCL, NSCLC; Clinical trial: } \\
\text { thyroid cancer, lymphoma, MM }\end{array}$ \\
\hline Alitretinoin/panretin & RXR & Agonist & $\begin{array}{l}\text { Cutaneous lesions of AIDS- } \\
\text { related Kaposi's sarcoma }\end{array}$ \\
\hline Peretinoin & RXR & Agonist & HCC \\
\hline 9cUAB30 & RXR & Agonist & $\begin{array}{l}\text { Clinical trials: breast cancer, non- } \\
\text { melanoma skin cancer }\end{array}$ \\
\hline IRX-4204 & RXR & Agonist & $\begin{array}{l}\text { Clinical trials: prostate cancer, } \\
\text { NSCLC }\end{array}$ \\
\hline TPST-1120 & PPAR $\alpha$ & Antagonist & $\begin{array}{l}\text { Clinical trials: hepatocellular } \\
\text { carcinoma, renal cell carcinoma, } \\
\text { mCRPC }\end{array}$ \\
\hline Troglitazone & $\operatorname{PPAR} \gamma$ & Agonist & Clinical trial: liposarcoma \\
\hline Pioglitazone & PPAR $\gamma$ & Agonist & $\begin{array}{l}\text { Clinical trials: Head and neck } \\
\text { cancer, bladder cancer, NSCLC, } \\
\text { chronic myeloid leukemia }\end{array}$ \\
\hline Rosiglitazone & PPAR $\gamma$ & Agonist & $\begin{array}{l}\text { Clinical trials: pituitary tumors, } \\
\text { liposarcoma, oral pre-malignant } \\
\text { lesions }\end{array}$ \\
\hline Efatutazonne & $\operatorname{PPAR} \gamma$ & Agonist & $\begin{array}{l}\text { Clinical trial: anaplastic thyroid } \\
\text { cancer, liposarcoma }\end{array}$ \\
\hline
\end{tabular}

Table 1 (continued)

\begin{tabular}{llll}
\hline Ligand & NR & Action & To treat \\
\hline CS-7017 & PPAR $\gamma$ & Agonist & $\begin{array}{l}\text { Clinical trials: NSCLC, } \\
\text { lymphoma, MM } \\
\text { Clinical trials: lymphoma, } \\
\text { advanced solid malignancies }\end{array}$ \\
\hline
\end{tabular}

results support the use of combined AR/GR targeting therapies for the treatment of resistant prostate cancer [17].

For these reasons, the mechanisms implicated in the development of resistance to AR inhibition in prostate cancer are multiple and complex (Fig. 3), and still poses major challenges to develop drugs with fewer side effects. A major problem is also the fact that there is no agreement as to whether prostate cancer is just one complex disease or whether there are different molecular subtypes. Multiple genomic alterations that result in distinct gene patterns and clinical implications have been also recently described [27], which will impact the design of future therapeutic drugs.

\section{Estrogen receptor: from biomarker to therapeutic marker in breast cancer}

Estrogens are steroid hormones that are important in the estrous cycle of humans and other animals, being the primary female sex hormones. The biological effects of estrogens are primarily mediated through the binding and activation of ER $\alpha$ (NR3A1) and ER $\beta$ (NR3A2). The expression and activity of ERs are important for normal development and function in various tissues, including endometrium, ovary and breast, and are also implicated in tumorigenesis [28]. In this section, we will focus on the roles of ER $\alpha$, the major ER in breast cancer, although some activities of ER $\beta$ have also been reported [29,30].

The classical definitions of breast cancer subtypes based on histopathological analysis, included both ER and progesterone receptor (PR) expression, which are prognostic factors. This has been further refined by the identification of the molecular subtypes of breast tumours based on their molecular profiles and their consequent association with clinical outcomes [31,32], providing new opportunities for tumour classification and prognostic tools. Exposure to ovarian hormones, including estrogen, has been associated with increased risk of developing breast cancer [33]. Approximately $75 \%$ of primary breast cancers express ER and these tumours show good overall patient survival. Patients with ER-positive tumours are treated with endocrine therapy, commonly in the form of tamoxifen (an ER-antagonist) or aromatase inhibitors (which lead to estrogen deprivation). Tamoxifen belongs to a group of ligands called selective ER modulators (SERMs) (Table 1), which have been developed to achieve improved safety profiles because they differentially modulate the activity of ER in a context specific manner. Tamoxifen competes with estrogen for ER binding and prevents LBD-mediated coregulator recruitment. In addition, tamoxifen can work as a partial agonist in other tissues, such as endometrium, since it promotes the activation of the AF1 domain and thus it poses an increased risk of endometrial cancer [34]. Another strategy is to use drugs that degrade ER, selective ER degraders or downregulators (SERDs), designed to overcome the agonistic effects of SERMs. Among SERDs, fulvestrant is an effective treatment for advanced breast cancer in postmenopausal women [35] (Table 1) and has enormous potential in combination therapy with other inhibitors [36]. Aromatase inhibitors were developed to stop estrogen production by inactivating aromatase (the enzyme responsible for estrogen synthesis) and they do not present partial agonist activity [37]. Three aromatase inhibitors are mostly used in the clinic, anastrozole, letrozole and exemestane. However, as it is the case for other types of therapy (including radiation and chemotherapy), therapy failure inevitably occurs in many cases [38]. Indeed, the development of resistance to different types of aromatase inhibitors has been well documented [39]. Futhermore, a recent meta-analysis showed 


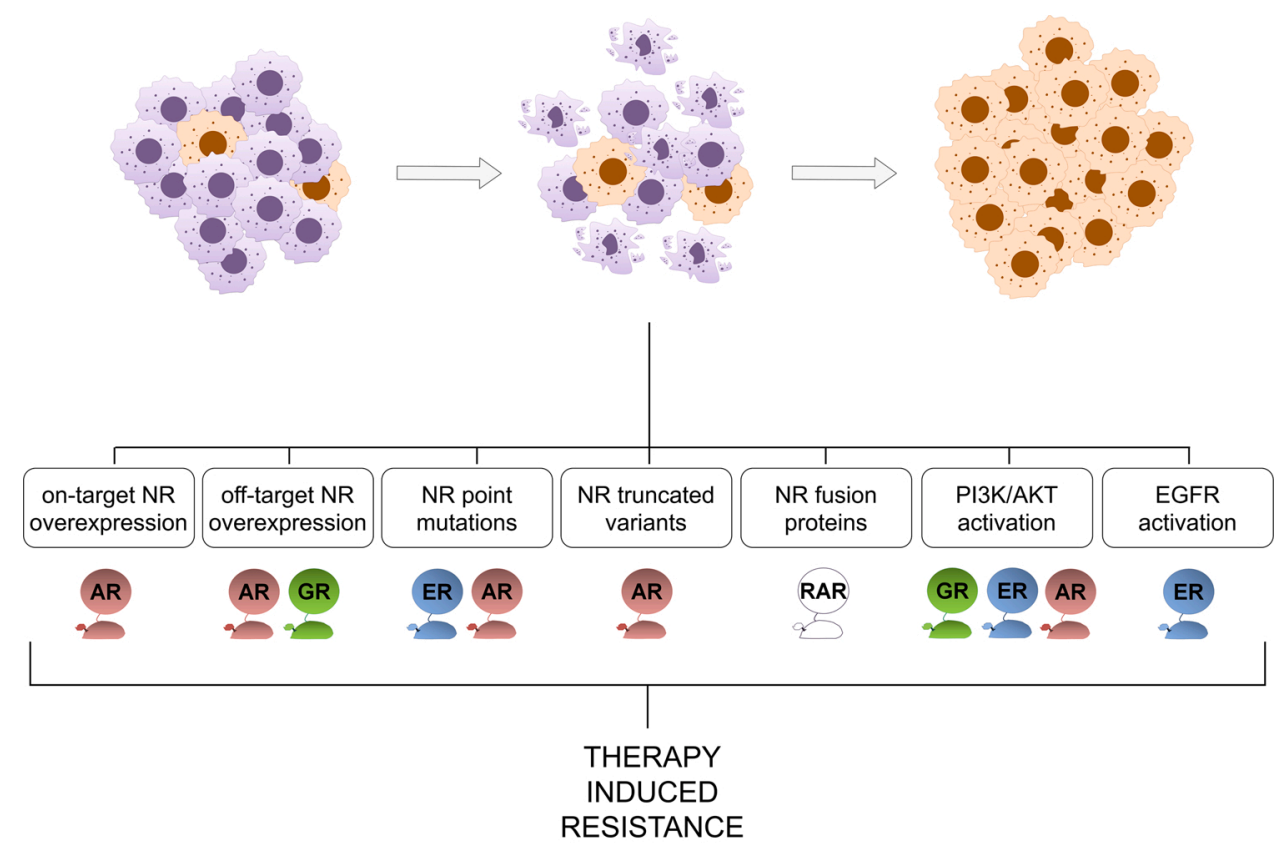

Fig. 3. Mechanisms underlying therapeutic-induced resistance involving NRs. Tumour regression by therapies targeting NR function is bypassed by different adaptation events. More than one molecular mechanisms can be found in different NR-driven tumours, meaning structural changes in the on-target NR, participation of a second off-target NR or the activation of parallel signalling pathways such as PI3K/AKT and EGFR.

that even after 20 years of tamoxifen usage, the risk of recurrence continues [40].

Given the high incidence rates of the disease, development of resistance to endocrine therapy and progression to metastasis remains a critical clinical problem, since the major cause of death in breast cancer is metastasis to distant organs. The etiology of endocrine therapy resistance is complex and diverse molecular mechanisms have been revealed over the years to be implicated in this process. Analysis of the genomic landscape of metastatic breast cancers has identified nine driver genes that were the most frequently mutated in metastasis from ER-positive tumours, including those encoding for AKT1 and estrogen receptor 1 (ESR1) [41]. Targeting components of the PI3K-AKT-mTOR pathway has been widely tested to treat endocrine refractory disease [42]. Dysregulation of the epidermal growth factor receptor (EGFR) family and their ligands has been reported [43], although results from clinical trials testing EGFR inhibitors in endocrine treatment-resistant breast cancer have been modest $[44,45]$. Variations of cell cycle components are also common in ER-positive breast cancer, including amplification of cyclin D1, gene copy gain of CDK4 and loss of negative regulators such as p16 and p18. Development of CDK4/6 inhibitors are now approved by the Food and Drug Administration (FDA) for use in combination with endocrine therapy to treat metastatic breast cancer, although acquired resistance quickly develops [46]. It is now well established that alterations in ESR1 itself, such as amplifications or chromosomal aberrations, have been detected in a subset of primary tumours and have been shown to be further enriched in recurrent and metastatic disease $[41,47,48]$. In addition, point mutations have been identified in endocrine resistant metastatic breast tumours, although those are particularly enriched in tumours pre-treated with aromatase inhibitors [49,50].

Breast cancers, like most tumours, are hypoxic and high levels of hypoxia-inducible transcription factors (HIF) correlate with poor prognosis in breast cancer patients. Hypoxia induces ER phosphorylation in the absence of estrogen [51] and alterations in ER phosphorylation can have a profound impact on ER function in breast cancer [52]. In addition, hypoxia reduces ER expression and transcriptional activity in breast cancer cells [53] and, conversely, adjuvant tamoxifen treatment has been shown to increase HIF1 $\alpha$-positivity, which is related to tamoxifen resistance and poor prognosis [54]. These findings support the notion that the loss of ER activity is associated with worse prognosis. Indeed, although ER expression is often maintained during development of resistance to endocrine therapy, its activity is frequently lost, as indicated by reduced levels of PR [55], a marker of functional ER. In addition, the loss of PR may be due to increased growth factor signalling activity, as a mechanism of resistance, leading to hyperactive crosstalk with ER signalling [56]. The analysis of ER signalling in normal breast epithelial cells and primary tumours has shown that tumour-specific ER signalling is gained during breast tumorigenesis [57], suggesting that further understanding of ER role in normal and cancer cells is still warranted.

In addition to estrogens, ER can be activated by the action of the oxysterol 27-hydroxycholesterol (HC) [58,59]. This compound is a primary metabolite of cholesterol and is considered an endogenously occurring SERM. Depending on the cellular context, 27-HC can act as an ER antagonist or as a partial ER agonist, which is the case in ER + breast cancer cells, where it promotes proliferation. Indeed, evidence from murine models and breast cancer cells suggests that the promoting effects of cholesterol on breast cancer progression may be mediated by its conversion to 27-HC (reviewed in [60]).

Cancer heterogeneity is now well appreciated, both among patients and within each tumour at molecular, phenotypic and functional levels, complicating diagnosis and presenting challenges for cancer therapy. Molecular and cellular complexity allows the tumours to evolve and evade currently used therapeutics. Accumulated evidence supports the presence of a small fraction of cells with characteristics of stem cells, cancer stem cells (CSCs), which have been implicated in tumour 
initiation and resistance to current forms of therapy. The identification of stem cells in the normal breast [61] and in cancer [62,63] has originated a new vision of the disease and new hopes for its prevention, prognosis and treatment. Estrogen reduces the pool of stem cells in healthy breast epithelial cells [64], which could provide an explanation for the better prognosis of ER-positive breast tumours, since it has been found that poorly differentiated breast cancers contain more CSCs than well-differentiated tumours with good prognosis [65]. Interestingly, breast stem cells have low or absent ER expression [55,66], which allows breast CSCs to ignore the anti-proliferative effects of tamoxifen. In contrast, treatment with tamoxifen leads to increased CSC content and, as a consequence, tamoxifen resistant tumours are enriched in CSCs, with enhanced expression of the embryonic stem cell factor SRY-box transcription factor (SOX)2 [55,67]. Furthermore, a regulatory axis has been identified between SOX2 and SOX9, which maintains human breast luminal progenitor and breast CSCs, suggesting common signalling pathways in normal and cancer stem cells [68]. Importantly, the expression of Sox 2 and Sox 9 stem cell markers is down-regulated by estrogen and induced by tamoxifen, supporting the notion that ER-positive tumours are more differentiated than resistant tumours or those that lack ER. Furthermore, enhanced CSC mitochondrial metabolism has been linked to resistance and inhibitors that target the large mitochondrial ribosome are able to prevent tamoxifen resistance and cancer metastasis [69]. An important clinical implication of the existence of CSCs within the tumour is that they become novel therapeutic targets and, therefore, combinatorial treatment strategies should be considered to address tumour heterogeneity.

To summarize, resistance to hormone therapy presents multiple mechanisms, including activation of the PI3K/AKT or EGFR signalling pathways, ER phosphorylation and mutations, epigenetics, cell cycle deregulation and CSCs and tumour heterogeneity (Fig. 3). Moreover, the implication of other steroid hormone receptors, beyond ER and PR, in breast cancer has also been studied, including RAR, VDR, AR and GR, among others [70]. For example, AR is expressed in the majority of ER-positive breast tumours, however, increased AR levels reduce the response to endocrine therapy, which has paved the way for a number of clinical trials using AR antagonists to treat advanced breast cancer [71].

In conclusion, in addition to ER, several NRs present opportunities to introduce combinatorial treatments to target this complex disease and reduce the development of tumour recurrence and metastasis.

\section{Glucocorticoid receptor: a dual role as tumour promoter or suppressor}

Glucocorticoids (GCs) are steroid hormones that are primarily produced in the adrenal gland in response to stress and are necessary to regulate numerous physiological processes. The biological actions of GCs are mediated by GR (NR3C1), which is ubiquitously expressed. GCs are very effective anti-proliferative and anti-inflammatory agents currently used in the clinics. In general, GR-mediated transactivation contributes to the efficacy of GCs by inducing the transcription of antiinflammatory mediators such as dual specificity phosphatase (DUSP)1, NFKB inhibitor alpha (NFKBIA), and GC-induced leucine zipper (GILZ) and of anti-proliferative mediators such as p21 (CDKN1A), while GRmediated transrepression antagonizes the activation of proliferative and pro-inflammatory transcription factors such as AP-1 and $\mathrm{NF \kappa B}$ [72-75].

GCs are the standard therapy for treating malignancies of the lymphoid lineage including leukemia, lymphomas, and multiple myeloma due to their effects promoting apoptosis and arresting cell growth in cells of the immune system [76,77] (Table 1). Although GCs alone are not curative, the initial response to GCs in children with acute lymphoblastic leukemia (ALL) is the best predictor of the overall outcome to full treatment. GCs (dexamethasone or prednisone) are routinely administered in combination with other agents (such as vincristine, mercaptopurine, asparaginase, and methotrexate), leading to complete remission in approximately $90 \%$ of children with both B and T-cell ALL [76]. In this context, GR induces apoptosis in a cell-autonomous manner by modulating the balance between pro- and anti-apoptotic mediators through the transcriptional regulation of apoptosis-related genes (B-cell lymphoma 2 (Bcl2) family) and the inhibition of survival factors (Myc). Unfortunately, some patients with ALL are resistant to GCs due to several factors that prevent GC-induced cell death including the imbalanced expression of Bcl2 family members. GCs are also successfully used in combination with other drugs (thalidomide, cyclophosphamide, and proteasome inhibitors) for treating multiple myeloma [76].

In non-hematopoietic cancers, the overall efficacy of GCs is controversial and at most, their use (as monotherapy or adjuvants) only provides partial benefits in certain hormone-driven cancers [78]. Recent findings indicate that in breast and prostate cancers, whether GCs promote or inhibit tumour progression depends on the functional crosstalk between GR and other NRs of the steroid subfamily, namely ER or AR [78]. Indeed, high levels of GR correlated with poor prognosis in ER negative breast cancer and ovarian cancer, and also contributed to the progression of CRPC or the resistance to the AR antagonist enzalutamide. The fact that GR and AR are structural and functionally similar, in particular in their DBD, theoretically allows their binding to identical DNA sequences [79]. Indeed, GR binds to more than $50 \%$ of AR binding sites in enzalutamide-resistant cells. Therefore, GR activation may represent an escape mechanism for tumour cells in an attempt to compensate for the loss of ER or AR (Fig. 3). Consistent with this, the use of GR antagonists restored the sensitivity of mCRPC to AR blockade supporting the usefulness of combination therapies [26].

GCs are not prescribed for the treatment of other epithelial cancers such as non-melanoma skin cancer. However, experimental data from mouse models demonstrated that GR acted as tumour suppressor in chemically induced skin tumours [80-82]. Mice with gain- and loss-of-function of GR showed reduced and increased susceptibility, respectively, to the onset, development, and malignization of skin tumours. In these epithelial tumours, GR decreased epidermal cell proliferation and inflammation by antagonizing PI3K/AKT/NFאB activities $[80,81]$.

Finally, GCs are commonly used in non-hematopoietic cancers as adjuvant in chemo- or radio-therapy due to their ability to ameliorate several associated side effects. However, the long-term use of GCs is restricted by the GC accompanying adverse effects including metabolic effects, muscle wasting and osteoporosis [83]. This highlights the need of developing strategies that improve the beneficial/risk ratio of GCs.

The precise molecular mechanisms underlying the multiple actions of GR in the context of cancer remain unclear [77]. In epithelial cancers, GR may affect cell survival by inhibiting p53, activating p38 and AKT signalling, or stimulating the secretion of pro-inflammatory cytokines such as interleukin (IL)-6 [84-86]. In breast cancer, GC anti-apoptotic effects are due to the induction of DUSP1 and NFKBIA, as they inhibit MAPK and NFKB pathways, respectively [87-90]. GILZ is a major mediator of GC anti-inflammatory effects in many cell types by inhibiting Ras, AP-1 and NFKB signalling. These actions should contribute to alleviate inflammation-related tumour growth, metastasis, and conversion. However, as GILZ also mediates immunosuppression, it could enhance tumour development. Therefore, GILZ can either promote or inhibit tumour growth depending on the context [91]. It seems thus necessary to identify the cell-type specific genes regulated by GR in each tissue as well as the specific coregulators that would allow selectively enhancing beneficial GR functions.

GR loss occurs in many cancers, and may cause malignant transformation [92,93]. However, the role of GC signalling in tumour progression and metastasis is greatly unknown. Overall, GCs seem to inhibit cell migration, invasion, and angiogenesis as well as down-regulate pro-angiogenic factors such as vascular endothelial growth factor (VEGF) and IL-8. GCs are also common palliatives in metastatic cancers (lung, bladder) used to prevent hypersensitivity reaction and skin rashes 
[76]. However, stress- and aging-related cancers have been associated with increased GC levels concomitant with the dysregulation of the hypothalamus-pituitary-adrenal axis. The seemingly controversial actions of GCs are particularly relevant in the immune system, which becomes dysregulated at some point in all cancers. In this regard, GCs constitute a double sword-edge as their intended immunosuppressive actions can simultaneously reduce the capacity of the immune system to mount a response against cancer.

In addition, several oxysterols have been reported to behave as GR ligands, thus modifying the action of classical GC agonists on GR. For example, 6-oxo-cholestan-3 $\beta, 5 \alpha$-diol (OCDO) can bind to GR, inducing its nuclear translocation, and regulating gene expression [94]. However, the resulting transcriptional outcome is different from that elicited by cortisol or dexamethasone. Given that OCDO levels are increased in breast cancer samples relative to healthy tissue, and that elevated GR expression/function correlates with poor therapeutic response or prognosis in these tumours [94,95], novel therapeutic strategies could be aimed to targeting this metabolite in breast cancer or other epithelial cancers.

\section{Anti-tumorigenic and anti-metastatic actions of the thyroid hormone receptor $\beta$}

Thyroid hormones (thyroxine (T4) and triiodothyronine (T3)) and thyroid hormone receptors (TRs) are crucial regulators of growth, development and metabolism, affecting virtually all cells in the organism [96]. Two different genes encode TR $\alpha$ (NR1A1) and TR $\beta$ (NR1A2) proteins, respectively, which are widely expressed. In general, TRs can bind response elements on their target genes either as monomers or, preferentially, as heterodimers with RXR [1].

Besides their classical actions, thyroid hormones also play important roles in cell proliferation and cancer [97,98]. Since these hormones are highly pleiotropic, the different TR isotypes might have opposing effects depending on the cell type, the cellular context or the transformation status [96]. In addition, it has been proposed that thyroid hormones exert non-genomic actions that are initiated at the cell membrane, which could be mediated by a fraction of membrane-associated NRs, or by the occupancy of putative membrane receptors, such as integrin $\alpha \mathrm{V} \beta 3$ [99], adding to the complexity of the effects of thyroid hormones in normal and neoplastic cells.

The first evidence connecting TRs with cancer was the discovery that TR $\alpha$ is the cellular counterpart of the v-erbA oncogene of the erythroblastosis virus, which causes avian erythroleukemia and sarcomas. This oncogene has a constitutive dominant-negative activity that inhibits the actions of endogenous TRs. Moreover, mice transgenic for v-erbA develop hepatocellular carcinomas (HCC) [100], reinforcing the idea that TRs could have tumour suppressor activity and that the loss of their function could result in a selective advantage for cellular transformation and tumour growth. In addition, reduced expression, anomalous cellular localization and/or alterations of the TR $\beta$ gene occur in many types of human tumours [98]. These alterations include point mutations, deletions, loss of heterozygosity or biallelic inactivation by promoter methylation, and most of the TR $\beta$ mutants found in tumours also have a dominant-negative activity, acting as TR inhibitors. The fact that TR $\beta$ could function as a tumour suppressor was also shown in mouse models of metastatic follicular thyroid carcinoma [101], mammary tumours [102] and chemical skin carcinogenesis [103].

Interestingly, TR deficiency inhibits benign tumour formation at early stages of skin carcinogenesis, whereas it increases malignization at later stages, indicating that TRs could mediate divergent effects on cell proliferation and malignant transformation. These diverging effects are very clear in the case of the liver. Thyroid hormone administration to mice causes liver hyperplasia [104] and TR $\beta$, the main liver TR, mediates the effect of the hormone in promoting hepatocyte proliferation in response to hepatectomy [105]. However, thyroid hormones induce a rapid regression of carcinogen-induced hepatic nodules in rodents, reducing the incidence of HCC and lung metastasis [106]. These findings are in agreement with the fact that hypothyroidism is considered a risk factor for the development of hepatocarcinoma in humans [107] and that the down-regulation of TR $\beta$ is an early event in human and rat hepatocarcinoma development [108].

Contrary to the well-accepted role of $\operatorname{TR} \beta$ as a tumour suppressor, TR $\alpha$ can have oncogenic effects by cooperating with the WNT pathway in the induction of intestinal tumorigenesis in mice [109]. This contrasts with the selective loss of TR $\beta$ in human colon carcinoma [110] and with its expression being associated with a benign phenotype [111]. Both receptors may also have an opposite role in breast cancer, where TR $\alpha$ expression is high and TR $\beta$ expression is lost $[112,113]$. In fact, hypothyroid patients have been reported to present both a higher and a reduced incidence of breast carcinomas [114]. These confounding effects could be secondary not only to thyroid hormone binding to different receptor isotypes, but also to the profound metabolic changes associated with hypothyroidism. In this sense, tumour growth is retarded in hypothyroid immunodeficient mice inoculated with both parental and TR $\beta$-expressing mammary tumour cells, but hypothyroidism also increases the number of invasion fronts of the tumours, the infiltration to neighbouring tissues and metastatic growth [115]. Such divergent effects may contribute to explain the contradictory reports on the influence of hypothyroidism in human breast cancer.

The re-expression of TR $\beta$ in human liver and breast cancer cell lines that have lost receptor expression results in the suppression of proliferation, migration and invasion in cultured cells, and in tumour growth retardation, partial mesenchymal to epithelial cell transition and suppression of metastasis in nude mice [103]. Several mechanisms involved in the anti-tumorigenic and anti-metastatic effects of TR $\beta$ have been identified. Among them, thyroid hormones can induce cellular senescence in the liver, a mechanism that is believed to act as a first barrier against cellular transformation and tumour development [116]. This action is mediated by binding to TR $\beta$, and not to TR $\alpha$ [117], and may be an important component of the initial tumour suppressor activity of the receptor. In addition, TR $\beta$ induces the transcription of microRNAs (miRNAs) miR-424 and miR-503, which belong to the miR-16 family, known for their capacity to down-regulate cell proliferation, migration and invasion. Induction of these miRNAs mediates some of the anti-proliferative and anti-metastatic actions of T3 in cancer cells [118]. Furthermore, TRs can antagonize the actions of the transforming growth factor beta (TGF $\beta$ ) pathway, thus inhibiting tumour cell proliferation and migration, and alleviating fibrosis $[119,120]$. TR $\beta$ also blocks the mitogenic action of other growth factors suppressing the activation of MAPK and PI3K signalling pathways, which are critical for cell proliferation and invasion [103]. Finally, tumour lymphangiogenesis, which is a main event in the metastatic spread of breast cancer tumours, and sentinel lymph node invasion is also inhibited by TR $\beta$ [121].

Genes that are relevant for metastatic progression have been identified [122]. Strikingly, TR $\beta$ coordinately down-regulates the expression of many pro-metastatic genes both in cultured cells and in tumours [103], and represses the expression of genes encoding for VEGF-C and VEGF-D [121], which are crucial regulators of lymphangiogenesis. NCoR, which is inactivated in various solid human tumours [123], plays a key role in the anti-tumorigenic and anti-metastatic actions of TR $\beta$. In the absence of NCoR, tumour xenografts were bigger, metastatic growth was enhanced and the inhibitory effect of TR $\beta$ in tumour growth, metastasis and lymphangiogenesis was significantly attenuated [120]. The relevance of these results is supported by the fact that NCoR and TR $\beta$ transcripts are significantly reduced in human hepatocarcinoma tumours when compared with normal tissue, with a strong correlation between the levels of both transcripts. These genes are also down-regulated in the more aggressive ER-negative human breast tumours in comparison to ER-positive tumours with better prognosis [120]. In addition, NCoR and TR $\beta$ transcripts correlate negatively with those derived from lymphangiogenic genes [121], suggesting that NCoR is important for the silencing of pro-metastatic and lymphangiogenic 
genes by TR $\beta$.

A subpopulation of CSCs with capacity for self-renewal, which can grow in culture as mammospheres, is believed to drive initiation, progression, and relapse of breast tumours [124]. The tumour suppressor actions of TR $\beta$ may be also related to the regulation of the CSC population. Indeed, the treatment of TR $\beta$-expressing breast cancer cells with thyroid hormone decreases significantly the self-renewal capacity of CSCs, the efficiency of mammosphere formation, the expression of pluripotency factors within the mammospheres, and the tumour initiating capacity in immunodeficient mice, indicating that TR $\beta$ limits the breast CSC population [125].

\section{RAR: a paradigm of cancer cell differentiation therapeutic strategy}

RARs regulate the expression of a vast array of genes that control cell proliferation, differentiation and survival as well as full body homeostasis [126]. RARs consist of three subtypes, RAR $\alpha$ (NR1B1), RAR $\beta$ (NR1B2) and RAR $\gamma$ (NR1B3), encoded by separate genes. Abundant levels of RAR $\alpha$ are detected in most tissues, whereas the other two isotypes are more abundant in specific tissues, e.g. RAR $\beta$ in retina and RAR $\gamma$ in esophagus and skin. RARs are activated by retinoids, endogenously-derived from vitamin A metabolites, such as all-trans retinoid acid (ATRA) [127].

RARs inhibit cell cycle progression by the direct transcriptional activation of the p21 cell-cycle inhibitor, which correlates with cell differentiation [128]. In addition, RAR activation may also cause cell death by inducing the tumour necrosis factor (TNF)-related apoptosis-inducing ligand pathway [129]. In adulthood, RARs are key players in the regulation of cell renewal, with essential roles in tissue stem cells [126].

Alterations in the functionality of RARs, caused by dysregulated gene expression, mutations, fusions to other proteins, or anomalous posttranslational modifications, are associated to neoplasia and malignant cell transformation [126]. The most representative example is found in acute promyelocytic leukemia (APL), a subtype of acute myeloid leukemia (AML), in which oncogenic RAR $\alpha$ fusion proteins are generated by diverse chromosomal translocation events. The chromosomal translocation (t15;17)(q22:q11), which renders the promyelocytic leukemia (PML)-RAR $\alpha$ fusion protein, is found in $95 \%$ of all APL cases. Despite the fact that PML-RAR retains the LBD of RAR, this fusion protein is refractory to the physiological levels of ATRA. Under these conditions, PML-RAR binds more strongly to HDAC-corepressor complexes than the RAR-RXR heterodimer, thus leading to a constitutively silenced gene expression program. However, the administration of pharmacological doses of ATRA (in combination with arsenic trioxide) is very effective as cancer cell differentiation therapy because it favours the dissociation of PML-RAR from HDAC-corepressor complexes, thus reverting the differentiation blockade at the promyelocytic stage [130] (Table 1). Nonetheless, some leukemic stem cells and other less common RAR fusion proteins are unresponsive to ATRA but, upon treatment with HDAC inhibitors, the sensitivity to ATRA is restored [131].

In particular for the RAR $\beta 2$ isoform, compelling evidence indicates that it has tumour suppressive activity. In this regard, the loss of RAR $\beta 2$ expression due to chromosome rearrangements or epigenetic mechanisms has been documented in a variety of cancer types, including hepatocarcinoma, breast, lung, prostate, and head and neck cancers, and it positively correlates with tumour grade [132]. Moreover, the expression of the RAR $\beta 4$ isoform is increased in some types of cancer and inversely correlates with RAR $\beta 2$ abundance. Notably, RAR $\beta 4$ almost lacks the $\mathrm{N}$-terminal domain and seems to function as a dominant-negative of RAR $\beta 2$ because of its ability to heterodimerize with RXR. The recovery of RAR $\beta 2$ expression in patients treated with RAR agonists is associated to a positive clinical response. In the same line, beneficial effects of retinoid administration in APL, head/neck and skin cancers correlated with the induction of RAR $\beta$ expression [133].
Retinoids also inhibit UV-induced skin cancer development in patients of xeroderma pigmentosum. In this regard, in experimental models for chemically-induced skin carcinogenesis, retinoid treatment showed effectiveness in inhibiting the appearance of squamous papilloma, in correlation with the ability of RAR to block AP-1 activity [134].

Despite the beneficial effects of retinoid chemotherapy in some types of cancer, the use of ATRA is limited due to its teratogenic effects and remains controversial in solid tumours because of mechanisms conferring retinoic acid resistance and toxicity syndrome [135] (Fig. 3), which implies that further studies are required to test the efficacy of isoform-selective RAR ligands and/or alternative combinatorial therapies overcoming such resistance.

\section{Anti-carcinogenic activities of RXR $\alpha$}

RXRs play critical roles in a plethora of physiological processes, including embryo development, cell differentiation, metabolism and organ homeostasis. The receptor has three isotypes, RXR $\alpha$ (NR2B1), RXR $\beta$ (NR2B2), and RXR $\gamma$ (NR2B3). RXR $\alpha$ shows abundant expression in the liver, kidney, epidermis and spleen; RXR $\beta$ is ubiquitously expressed; and the most restricted of the three receptors is RXR $\gamma$, which is abundantly expressed in muscle and brain. RXR has a unique cooperative function because of its ability to form homodimers as well as heterodimers with several other NRs, such as RARs, TRs, PPARs and LXRs. RXR binds the vitamin A derivatives 9-cis-retinoic acid and 9-cis-13,14-dihydroretinoic acid, some fatty acids, such as docosahexanoic acid and phytanic acid, and selective RXR ligands known as rexinoids [127].

Ligands that activate $\mathrm{RXR} \alpha$ display potent anti-carcinogenic activities by inhibiting cancer cell growth and promoting apoptosis [136] and by repressing inflammatory pathways critical for carcinogenesis [137, 138]. Alterations in the expression and function of $\operatorname{RXR} \alpha$ are indeed implicated in the development of a number of cancers. The targeted disruption of the RXR $\alpha$ gene, for example, leads to pre-neoplastic lesions in the prostate and to cervical metaplasia [139,140]. Consistently, the diminished expression of $\mathrm{RXR} \alpha$ [141-143] or its malfunction due to phosphorylation by the Ras-MAPK pathway [144,145] are associated with the development of several forms of cancer. In addition, hotspot mutations (S427 F/Y) in the RXRA gene are present in approximately $5 \%$ of bladder cancer samples [146,147]. An oncogenic role for the S427 $\mathrm{F} / \mathrm{Y}$ mutation has been proposed in luminal bladder cancer, potentially through the aberrant activation of other dimerization partners (e.g. $\operatorname{PPAR} \gamma$ ) in the absence of ligand [148].

Interestingly, a cytosolic truncated form of $\mathrm{RXR} \alpha$ exists in several tumours and cancer cell lines as a consequence of proteolytic cleavage [149]. Aberrant $\operatorname{RXR} \alpha$ function due to limited proteolysis may cause resistance to the anti-proliferative effects of retinoids [150] and promote cancer cell survival by activating the PI3K/AKT pathway [151]. The overexpression of this form accelerated the development of colitis-associated colon cancer in mice through increased IL-6 signalling in myeloid cells [152].

Because of all these considerations $\operatorname{RXR} \alpha$ represents an important target for the pharmacologic intervention of cancer. The administration of selective RXR agonists have a well-established beneficial effect in solid tumours because of their capacity to induce the differentiation and/or apoptosis of cancer cells [136]. The endogenous RXR ligand 9-cis-retinoic acid (also known as alitretinoin or panretin) is indicated in the topical treatment of cutaneous lesions of acquired immune deficiency syndrome (AIDS)-related Kaposi's sarcoma [153], whereas 13-cis-retinoic acid (isotretinoin) has therapeutic potential in the treatment of several other types of cancer $[154,155]$.

The synthetic RXR $\alpha$ ligand bexarotene (also known as targretin) is used currently for treating refractory cutaneous $\mathrm{T}$ cell lymphoma (CTCL) [156] (Table 1). Bexarotene acted synergistically with standard first-line cytotoxic chemotherapy [157] and overcame the acquired resistance to paclitaxel in non-small cell lung cancer (NSCLC) [158]. Interestingly, bexarotene also appeared to increase the survival of a segment of NSCLC 
patients developing high-grade hypertriglyceridemia [159,160].

RXR agonists, in combination with drugs that increase the levels of cyclic AMP, can induce the terminal granulocytic differentiation and apoptosis of AML cells that are unresponsive or resistant to ATRA therapy [161]. Consistently, clinical trials suggest that bexarotene may also be useful as combined therapy for AML [162]. The mechanism by which RXR agonists exert cell differentiation has been proposed to be independent of heterodimerization with RAR [163]. In contrast, the combined use of bexarotene with LXR agonists induced potent differentiation and cytotoxicity in AML cell lines and primary human AML cells [163], which raises the possibility that the combined activation of RXR-LXR heterodimers might have a potential role in the differentiation therapy of AML.

Apart from agonistic ligands, some compounds target specific properties of the RXR $\alpha$ molecule. This is the case of acyclic retinoid (also known as peretinoin), a synthetic retinoid that binds to both RXR and RAR and prevents the phosphorylation of RXR $\alpha$ by the Ras/MAPK pathway through an undefined mechanism [164]. Clinical studies have shown that it is effective in suppressing HCC recurrence and improving patient survival rates following curative therapy [164]. Peretinoin not only enhances the expression of retinoid target genes in the liver but also modulates various signal transduction pathways involved in hepatocarcinogenesis [165]. On the other hand, the naturally occurring xanthone CF31 is able to inhibit the interaction between the truncated form of RXR $\alpha$ and PI3K, thus facilitating the induction of cell death in response to TNF $\alpha$ [166].

In contrast to the beneficial effects of rexinoids in a number of malignancies, RXR $\alpha$ has been demonstrated to be a binding partner of the PML-RAR fusion, which suggests a contributing role for RXR $\alpha$ in APL $[167,168]$. Genome-wide epigenetic studies suggested that the PML-RAR $\alpha$-RXR complex acts as a local chromatin modulator that is crucial for oncogenic transformation and for the development of APL in transgenic mice [169], thus raising the possibility that RXR $\alpha$ may be a relevant therapeutic target also in APL.

The role of RXR expression specifically in the myeloid compartment and in the context of cancer has been recently addressed. In line with negative actions of RXRs in inflammatory responses and angiogenesis, RXR expression in myeloid cells has been shown to play a protective role against cancer cell migration and invasion [170]. RXR deletion in myeloid cells resulted in the increased expression of important determinants of premetastatic niche formation in the lung. Mechanistically, RXR mediated the repression of these genes through corepressor recruitment to DNA elements in a ligand-independent manner [170]. However, recent studies have shown that the expression of RXRs in tissue resident macrophages contributes to their accumulation in tumours and to ovarian tumour progression in mice [171], which raises the need to further explore the specific contribution of RXRs in the different cell compartments of the tumour microenvironment.

\section{PPARs display multiple functions that are pro and anti- tumoral}

The PPAR subfamily includes three members, PPAR $\alpha$ (NR1C1), PPARס (NR1C2), and PPAR $\gamma$ (NR1C3), which are activated by fatty acids, eicosanoids and numerous xenobiotics. Whereas the homology between the DBD domains of the three subtypes reaches up to $80 \%$ identity, their LBDs exhibit a lower degree of sequence homology, thereby allowing the binding of structurally different ligands that may account for the specific biological activities of the three PPAR isotypes.

The expression pattern of each PPAR in adult animals is tissuespecific. PPAR $\alpha$ is mainly expressed in the liver, where it activates fatty acid catabolism. PPAR $\delta$ is expressed ubiquitously and is implicated in fatty acid oxidation and keratinocyte differentiation. PPAR $\gamma$ is mainly expressed in adipose tissue, colon, kidney and immune cells, including lymphocytes and macrophages. PPAR $\gamma$ is an essential modulator of adipocyte differentiation, lipid storage and glucose metabolism, and plays important anti-inflammatory roles in macrophages [172]. In addition, PPARs are also involved in the control of central cellular processes including cell differentiation, proliferation, survival, and apoptosis [173]. Because of their roles at the crosstalk between metabolism and central cellular processes, PPARs have received interest as potential therapeutic targets for a variety of malignancies, including solid tumours, such as liver, lung, gastrointestinal, breast and prostate cancer, as well as leukemia [174,175].

The role of the PPAR $\alpha$ and PPAR $\delta$ isotypes in cancer is controversial. The chronic administration of PPAR $\alpha$ agonists in rodents results in a short-term pleiotropic response leading to liver hypertrophy and hyperplasia that is followed by the formation of HCC $[176,177]$. The development of such tumours occurs via an increase in oxidative stress, the induction of cell proliferation and the inhibition of apoptosis [176, 178]. Mice lacking PPAR $\alpha$ are resistant to clofibrate- and WY-14, 643 -induced hepatic neoplasia $[177,179]$. In contrast, epidemiological studies suggest that similar effects are unlikely to occur in humans [180, 181]. A number of experimental observations suggest major differences between rodents and humans in the response to PPAR $\alpha$ agonists [182-184], potentially due to the significantly lower expression of PPAR $\alpha$ in human hepatocytes, the inefficient ligand activation of human PPAR $\alpha$ [185], and the differential expression of coactivators and/or PPAR $\alpha$ variants. Another possible explanation suggests that human PPAR $\alpha$ does not exert carcinogenic effects, as the activation of a humanized PPAR $\alpha$ in transgenic mice results in the increased expression of genes that modulate lipid catabolism but does not induce hepatic tumours $[178,185]$. This finding raises the question of whether there are structural variations in the regulatory regions of genes involved in hepatocyte growth between humans and rodents that might be responsible for the differential response to PPAR $\alpha$ agonists [182,185,186]. In addition, murine, but not humanized, PPAR $\alpha$ down-regulated the let-7c miRNA cluster, which targets Myc. Therefore, the increased stability of Myc mRNA might contribute to enhance mitogenic signalling and hepatocyte proliferation in response to murine PPAR $\alpha$ activation [187].

Paradoxically, several other studies suggest that activating PPAR $\alpha$ could be useful for the prevention or treatment of different cancers. The administration of PPAR $\alpha$ agonists inhibited the growth of tumours derived from melanoma, glioblastoma, Lewis lung carcinoma, and fibrosarcoma cell lines, and of xenografts from A549 human lung cancer cells [188-190]. These inhibitory effects were mediated by the PPAR $\alpha$-dependent inhibition of endothelial cell proliferation and angiogenesis, via the suppression of epoxyeicosatrienoic acid biosynthesis [191,192]. In addition, PPAR $\alpha$ inhibited inflammatory signalling through repressive interaction with the p65 subunit of NFkB [193] and negatively influenced aerobic glycolysis (the Warburg effect) [194]. In this sense, the activation of PPAR $\alpha$ increased the mitochondrial oxidation of fatty acids, and inhibited the expression of glutaminase, thus reducing glutamine levels and limiting cancer cell growth [194,195]. Recently, intestinal PPAR $\alpha$ was also shown to protect against colon carcinogenesis via the regulation of DNA methyltransferase 1 and protein arginine methyltransferase 6 [196]. In the same line, the administration of fenofibrate protected transgenic mice expressing human $\operatorname{PPAR} \alpha$ from chemical-induced colon tumorigenesis [196].

Pro- and anti-tumorigenic roles have also been proposed for PPAR $\delta$ $[177,178]$. PPAR $\delta$ expression is up-regulated in various human cancers, including colorectal cancer [197-199], pancreatic cancer [200], and lung cancer [201]. In general, high PPAR $\delta$ expression in human cancers is associated with higher pathological grade and negative survival outcomes [197,202]. PPARס overexpression in intestinal epithelial cells in mice, which mimics the up-regulation of this protein in human colon cancer tissues, promoted chemical-induced colorectal tumorigenesis [203]. Moreover, a recently published study using unbiased global transcriptome analysis identified PPAR $\delta$ activation as a driver of intestinal stem cell transformation and tumour promotion in APCMin mice maintained on a high-fat diet, suggesting that PPAR $\delta$ may play a mechanistic role in obesity-driven cancers [204,205]. 
In contrast with the general pro-tumorigenic roles of PPAR $\delta$, a recent retrospective clinical study associated high PPARס expression in colorectal tumours with an increased survival rate following radiation treatment [206]. In addition, its oncosuppressive activity was also proposed in prostate cancer [207] and in chemically induced skin carcinogenesis [208,209].

The controversy regarding the role of PPAR $\delta$ in tumorigenesis is also evident in in vivo deletion studies in mice, in which the absence of this protein in the germline has either positive [210] or negative [211,212] effects on colon tumour development. Interestingly, in the PPAR $\delta$ knockout model in which a pro-tumorigenic effect was observed in the colon, tumour development after the implantation of melanoma or Lewis lung carcinoma cells was inhibited [213]. Likewise, backcrossing this model with MMTV-cyclooxygenase (COX)-2 transgenic mice resulted in the suppression of mammary gland tumour formation [214]. Such contradictory findings has prompted the interpretation that PPAR $\delta$ may play different roles depending on where it is specifically expressed; PPARס expression in stromal cells within the tumour microenvironment may promote tumorigenesis, whereas PPAR $\delta$ expression in cancer cells may suppress tumour growth [213].

Apart from the effects on tumour growth, a pro-metastatic role for PPAR $\delta$ has been suggested in different studies. The down-regulation of PPAR $\delta$ expression in human cancer cells strongly suppressed metastasis after their orthotopic injection in immunodeficient mouse models. These effects occurred via the suppression of the expression of important prometastatic genes in cancer cells and of critical metastatic events including angiogenesis, epithelial-mesenchymal transition, and cancer cell invasion and migration [197]. In addition, PPARס-deficiency in stromal cells also contributed to inhibit metastasis [197]. The activation of PPAR $\delta$ promoted the migration and invasion of highly metastatic melanoma cells by up-regulating the Snail Family transcriptional repressor 1 [215]. Furthermore, PPAR $\delta$ up-regulation in human colon, lung, and breast cancers correlated with reduced metastasis-free survival [197].

In contrast to the other members of the PPAR subfamily, PPAR $\gamma$ plays roles that are predominantly anti-tumorigenic. The activation of PPAR $\gamma$ inhibits growth, and either promotes apoptosis or induces the differentiation of a number of cancer cell lines in vitro and in vivo, including liposarcoma, prostate, breast, bladder and colon cancer cells [178]. Several mechanisms are involved in these actions, including the repression of cyclin D1, the induction of cell cycle inhibitors (e.g. p21, p27 and PTEN) or the up-regulation of pro-apoptotic factors (e.g. BAX and $\mathrm{BAD}$ ) [178]. An indirect mechanism affecting cell proliferation relies on the insulin sensitizing activity of the PPAR $\gamma$ agonists thiazolidinediones (TZDs), which may decrease hyperinsulinemia in patients of metabolic diseases associated to insulin resistance, and hence, prevent the mitogenic effects of insulin on malignant cells [216].

In addition to direct actions on transformed cells, inhibitory effects on the inflammatory response and on angiogenesis within the tumour microenvironment may contribute to the anti-tumorigenic activities of ligand-activated PPAR $\gamma$ [217]. Also, PPAR $\gamma$ activation counteracts the cancer-associated up-regulation of the WNT/ $\beta$-catenin pathway, which is important in cancer-related chronic inflammation and oxidative stress [218].

Of note, the tumour inhibitory action of TZDs was shown to be independent or only partially dependent on $\operatorname{PPAR} \gamma$, and initial clinical trials using TZDs as monotherapy failed to show significant effectiveness against cancer [219]. However, epidemiological studies have evidenced a reduction in the development of different types of cancer in diabetic patients treated with TZDs [220]. As mentioned above, it must be taken into account that the beneficial effect of TZDs-PPAR $\gamma$ may not be a consequence of direct anti-tumour actions alone, but result also from indirect effects leading to the amelioration of pro-tumorigenic conditions [217]. However, relevant discordances have emerged such as the increased risk of bladder cancer, non-Hodgkin lymphoma and melanoma in type 2 diabetes patients long-time treated with pioglitazone
[221,222]. Currently, numerous clinical trials are ongoing (in phase II and III) for the use of PPAR $\gamma$ ligands, including rosiglitazone, pioglitazone, efatutazone and troglitazone, as mono- or combined therapeutic agents for a long list of cancers with different clinical outputs [175] (Table 1).

In summary, the effects of PPARs on tumour progression are diverse and depend on the type of tissue and/or the PPAR ligand evaluated. Several variables, including the levels of expression of PPAR isotypes in the tumour microenvironment, the specific sets of genes regulated by each isotype, the relative abundance of coactivators and corepressors, and the possibility that ligands exert both PPAR-dependent and -independent activities, influence the capability of such ligands to modulate tumour growth.

\section{The modulation of lipid metabolism by liver $\mathrm{X}$ receptors as a promising strategy in cancer therapy}

Two subtypes of LXRs exist, LXR $\alpha$ (NR1H3) and LXR $\beta$ (NR1H2), with established roles in the control of lipid and glucose metabolism, and in the regulation of immune responses. LXR $\alpha$ is highly expressed in the liver, adipose tissue, intestine, kidney and lung, whereas LXR $\beta$ is present in most tissues. They can be naturally activated by specific endogenous oxysterols (e.g. 22(R)-HC, 24(S)-HC, 27-HC, and 24(S),25-epoxycholesterol) or the cholesterol precursor desmosterol. In addition, they can be activated by synthetic high-affinity agonists [223].

The effects of LXR activation as a potential therapy in cancer have been studied with raising interest in the last decade. Synthetic LXR ligands (e.g. TO901317 and GW3965) have potent anti-proliferative, cytostatic and pro-apoptotic activities in several cancer cell lines [224-227]. These effects translate into reduced tumour progression in murine models [225,226,228-232]. A number of molecular mechanisms involved in intracellular signalling and cell cycle progression have been shown to be affected by LXR activation in a cell-autonomous manner in different cancer cell types. These include the repression of positive cell cycle regulators (eg. cyclins and/or CDKs) [225,227,232-234], the up-regulation of cell cycle inhibitors (e.g. p21 or p27) [225,227, 235-237], the induction of suppressor of cytokine signalling 3 [228], and the interference with the $\beta$-catenin/WNT pathway [238]. In addition, LXR agonists are able to inhibit AKT pro-survival signalling [226] and to induce caspase-dependent cell death in several cancer cell lines $[225,226,229,230]$.

The accumulated evidences indicate that the transcriptional activation of genes involved in lipid homeostasis within cancer cells plays an essential role in the anti-tumoral actions of the LXR pathway. In this sense, the induction of the cholesterol and phospholipid transporter ATP-binding cassette $(\mathrm{ABC}) \mathrm{G} 1$, and the subsequent reduction in intracellular cholesterol levels, contribute to the anti-proliferative actions of LXRs in cancer cells [239]. Indeed, alterations in the structural characteristics of lipid rafts caused by the increased expression of ABCG1 was proposed as the basis for the reduced AKT phosphorylation in pancreatic cancer cells stimulated with LXR agonists [226].

In particular, glioblastoma cells are highly dependent on the uptake of cholesterol for survival due to dysregulated endogenous cholesterol synthesis [231]. LXR-623, which is a partial agonist for LXR $\alpha$ and a full agonist for LXR $\beta$, induced glioblastoma cell death through LXR $\beta$-dependent intracellular cholesterol depletion. This effect was consistent with the capacity of LXR-623 to induce the expression of two sets of targets in parallel: the E3 ubiquitin ligase inducible degrader of the low-density lipoprotein receptor (IDOL), a mechanism that limits the uptake of cholesterol-rich low-density lipoproteins, and the cholesterol transporters ABCA1 and ABCG1 that mediate cholesterol efflux.

The discovery of a different partial agonist for LXRs, dendrogenin A, allowed the identification of an additional role for LXR $\beta$ as inducer of lethal autophagy in human melanoma and AML cells [240]. Dendrogenin A is a naturally occurring steroidal alkaloid product of the enzymatic conjugation of a cholesterol derivative (5, 
$6 \alpha$-epoxycholesterol) and histamine [241]. Although the potential contribution of LXR $\alpha$ was not discarded, the partial agonism of LXR $\beta$ was proposed to mediate a complex combination of actions, including the direct transcriptional activation of other members of the NR family (nuclear receptor 77 (Nur77/NR4A1) and neuron-derived orphan receptor 1 (NOR1/NR4A3)) and of microtubule associated LC3, which is an important mediator of autophagosome formation [240]. In addition, dendrogenin A de-repressed the expression of transcription factor EB, a master transcriptional regulator of autophagy and lysosome biogenesis, by blocking the inhibitory action of LXR $\beta$ on this gene. These combinatorial effects were selective for dendrogenin A and were not observed in response to conventional full LXR agonists. Moreover, dendrogenin A induced characteristics of differentiation in human thyroid carcinoma cells in an LXR $\beta$-dependent manner [242].

In addition, the LXR pathway is able to promote a lipogenic program involving the increased expression of fatty acid synthase (FAS), which results in triacylglyceride accumulation. Induction of this program in prostate cancer cells resulted in cell cycle arrest [234]. However, an LXR inverse agonist, SR9243, which induces LXR-corepressor interaction and reduces the expression of genes controlling glycolysis and lipogenesis, inhibited the Warburg effect and caused apoptosis in a broad range of cancer cells [243]. These contrasting observations reflect the need to further clarify the exact role of LXR-mediated lipogenesis in tumour growth control.

The importance of secreted apolipoprotein E (ApoE), another direct LXR transcriptional target, as an inhibitor of the invasive capacity of melanoma cells has been consistently demonstrated [244]. ApoE secretion resulted in inhibitory effects on melanoma progression, angiogenesis and metastasis to the brain. Of note, the selective knockdown of LXR $\beta$, but not LXR $\alpha$, in melanoma cells blocked the ability of LXR agonists to suppress invasion and endothelial cell recruitment.

Apart from cancer cell-autonomous effects, LXR activation can also impact other cells within the tumour microenvironment. The activation of the LXR pathway altered endothelial cell cholesterol homeostasis, which affected the organization of lipid rafts in the plasma membrane [245]. These effects impaired VEGF receptor signalling and correlated with reduced tumour angiogenesis. In addition, stromal and endothelial cells may also contribute to the increase in ApoE levels in response to pharmacological LXR activation [244]. ApoE produced in vitro by LXR-treated macrophages reduced the proliferation and increased apoptosis of a human breast cancer cell line [246]. Moreover, the increase in ApoE levels following LXR agonism with GW3965 or a novel LXR agonist, RGX-104, induced the apoptosis of myeloid-derived suppressor cells (MDSC), resulting in decreased systemic and intratumoral levels of these cells in the context of melanoma [247]. These effects were associated with an augmented infiltration of activated cytotoxic T cells and pro-inflammatory helper T cells within the tumours, thus suggesting that the LXR-ApoE axis can exert anti-metastatic actions on cancer cells [244] while enhancing immune-mediated anti-tumoral responses [247]. In fact, RGX-104 and checkpoint blockade by anti-programmed cell death protein 1 (PD-1) antibodies displayed synergistic inhibitory effects on tumour growth in mice [247].

Whereas conventional LXR agonists have failed translation to the clinic due to adverse effects, RGX-104 is currently being tested in a phase 1, first-in-human, dose escalation and expansion study in patients with lymphoma or advanced solid malignancies under standard treatments, including anti-PD-1 immunotherapy [248] (Table 1). Preliminary data indicate that RGX-104 reduce the abundance of MDSCs in cancer patients with diverse forms of metastatic cancer [247]. In addition, the importance of the LXR pathway in tumour growth control is supported by the potential prognostic value of LXR $\alpha$ expression in HCC patients [249].

In contrast to the generalized anti-tumoral effects of synthetic LXR agonists, the LXR pathway has been also shown to participate in mechanisms for tumour immune evasion. In this sense, factors released by the tumour, potentially endogenous oxysterols, inhibited the expression of C-C chemokine receptor type 7 (CCR7) in dendritic cells through the activation of LXR $\alpha$. This mechanism impaired dendritic cell migration to lymph nodes, thus interfering with antigen presentation to $\mathrm{T}$ cells [250]. Other studies, however, have shown a requirement for LXR activation for efficient CCR7-dependent chemotaxis of dendritic cells and other myeloid cells [251,252], and the multifunctional enzyme CD38 emerged as an LXR transcriptional target mediating these effects in dendritic cells [251]. Therefore, these contrasting observations on the role of LXRs in dendritic cell chemotaxis raise the need to further investigate the type of molecules that are secreted in the tumour microenvironment and the way they act on the LXR pathway. On the other hand, hyaluronic acid produced within tumours has been recently shown to induce an increase in cholesterol efflux in tumour-associated macrophages through the activity of the cholesterol transporters ABCA1 and ABCG1. Increased cholesterol efflux promoted a pro-tumoral macrophage reprograming in response to IL-4 [253]. However, while these cholesterol transporters are conventional LXR targets, the involvement of LXRs in the actions of hyaluronic acid has not been established.

In summary, many of the actions of the LXR pathway translate into inhibitory effects on cancer cell proliferation or on the pro-tumoral activities of stromal cells, which directly or indirectly, derive from local changes in lipid metabolism. Therefore, the designing of improved ligands, and/or delivery strategies, that promote selective metabolic actions of LXRs within the tumour microenvironment deserve further investigation.

\section{Future perspectives}

Several NRs present opportunities for therapeutic intervention in cancer. As described in this review, established therapies or ongoing clinical trials exist based on the activation of several NRs (Table 1), either as monotherapy or in combination with chemotherapy or immunotherapy. In the case of PPARs, due to the fact that different isotypes exert complementary roles, a concept that has recently emerged is that dual- or pan-PPAR agonists may be more beneficial than agents targeting a single PPAR subtype. A candidate compound is bezafibrate, a pan-PPAR agonist, shown to reduce the development of colon cancer [254].

One of the major challenges in the field, however, is the development of side effects, as it often occurs after prolonged treatment with, for example, GCs [83], TZDs [174], or bexarotene [255]. This obstacle is also the reason why the progression of first-generation ligands for LXRs were stopped before reaching the clinics [256]. Novel synthetic ligands with less adverse effects and an improved therapeutic profile are currently under development for several NRs. In the case of GR, most of the side effects of GCs seem to rely on the GR transactivation function. For this reason, the designing of compounds able to selectively activate GR transrepression function, the so-called selective GR agonists and modulators (SEGRAMs), has become a major research focus and some of these molecules are currently in clinical trials [83]. In addition, a novel rexinoid capable of activating RXR with minimal toxicity offers therapeutic potential for the treatment of medulloblastoma [257]. Furthermore, the simultaneous activation of PPAR $\alpha$ and/or PPAR $\delta$ may be also a strategy to bypass the side effects of PPAR $\gamma$ agonists [174].

The second major obstacle in the field is the development of resistance to NR ligands. As described in this review, mutations and other mechanisms contribute to the acquired unresponsiveness of NRs to agonists or antagonists (Fig. 3). However, the molecular mechanisms underlying such resistance are far from being well understood and more detailed knowledge about the structural and functional properties of NRs in the context of cancer will facilitate the discovery and development of improved ligands. In this regard, the recently solved lowresolution of the full length AR structure may be an opportunity to develop novel anti-androgens with improved characteristics to avoid the development of resistance [258]. The use of alternative combinatorial 
therapies also needs to be addressed. Tumour heterogeneity implies that within the same tumour, not all cancer cells express the receptor, as shown with breast cancer stem cells lacking ER, thus enabling their capacity to avoid the effects of endocrine therapy [55]. This illustrates the need to combine therapies in order to target such complexity. Another strategy is to reduce the content of cancer stem cells through differentiation. An example discussed here that strengthens this concept is the effectiveness of rexinoids in inducing the terminal differentiation of AML cells that are resistant to ATRA [161].

Taken together, further studies are required to identify genes targeted by each NR agonist in a cell type-specific manner, and to define potential interactions between NRs and coregulators that selectively promote the beneficial functions of each NR. In addition, molecular studies exploring the structural aspects that govern NR-coregulator interaction in response to a given ligand and the acquisition of resistance are fundamental. These aspects may not only provide avenues for the designing of compounds with improved therapeutic potential, but may also help define combinatorial strategies that address the heterogeneity of tumours.

\section{Funding source}

All sources of funding should also be acknowledged and you should declare any involvement of study sponsors in the study design; collection, analysis and interpretation of data; the writing of the manuscript; the decision to submit the manuscript for publication. If the study sponsors had no such involvement, this should be stated.

\section{Declaration of Competing Interest}

The authors report no declarations of interest.

\section{Acknowledgements}

This work was supported by grants from the Spanish Ministry of Economy and Competitivity (MINECO) to AFV and CC (SAF2017-89510$\mathrm{R}$ ), to AA (SAF2017-83289-R), to MV (SAF2017-84934-R), to PP (SAF2017-88046-R), to EE (BFU2017-86906-R), and to the NuRCaMeIn network (SAF2017-90604REDT); grants from the Spanish Ministry of Science, Innovation and Universities (MCNU) and Fondo Europeo de Desarrollo Regional (FEDER) to MR (RTI2018-095928-B100) and AC (PID2019-104284RB-I00/AEI/10.13039/501100011033); a grant from Instituto de Salud Carlos III to AA (CIBERONC CB/16/00228); grants from the Autonomous Community of Madrid to AA (B2017/BMD-3724) and MR (MOIR-B2017/BMD-3684); grants from Fundació La Marató de TV3 to CC (201605-30), AFV (201605-31) and MR (201605-32); a grant from the Government of the Autonomous Community of Basque Country, Department of Industry, Tourism and Trade to MV (Elkartek, KK-2018/ 00054); and a grant from La Caixa to EEP (CaixaImpulse-CI-0018). JFD received a fellowship from the Spanish Ministry of Science, Innovation and Universities (FPI, PRE2018-085579). The CNIC is supported by the MCNU and the Pro CNIC Foundation and is a Severo Ochoa Centre of Excellence (SEV-2015-0505). CIC bioGUNE is a Severo Ochoa Centre of Excellence (SEV-2016-0644).

\section{References}

[1] R.M. Evans, D.J. Mangelsdorf, Nuclear receptors, RXR, and the big bang, Cell 157 (2014) 255-266, https://doi.org/10.1016/j.cell.2014.03.012.

[2] M.D. Long, M.J. Campbell, Pan-cancer analyses of the nuclear receptor superfamily, Nucl. Recept. Res. 2 (2015), https://doi.org/10.11131/2015/ 101182

[3] P. Fuentes-Prior, A. Rojas, A.T. Hagler, E. Estébanez-Perpiñá, Diversity of quaternary structures regulates nuclear receptor activities, Trends Biochem. Sci. (2019), https://doi.org/10.1016/j.tibs.2018.09.005.

[4] R. Sever, C.K. Glass, Signaling by nuclear receptors, Cold Spring Harb. Perspect. Biol. 5 (2013), https://doi.org/10.1101/cshperspect.a016709.
[5] X. Yu, P. Yi, R. Hamilton, H. Shen, M. Chen, C. Foulds, M. Mancini, S. Ludtke, Z. Wang, B. O'Malley, Structural insights of transcriptionally active, full-length androgen receptor coactivator complexes, Mol. Cell (2020), https://doi.org/ 10.1016/j.molcel.2020.06.031.

[6] L. Zhao, S. Zhou, J.Å. Gustafsson, Nuclear receptors: recent drug discovery for cancer therapies, Endocr. Rev. 40 (2019) 1207-1249, https://doi.org/10.1210/ er.2018-00222.

[7] C. Carlberg, A. Muñoz, An update on vitamin D signaling and cancer, Semin. Cancer Biol. S1044-579X (20) (2020) 30114, https://doi.org/10.1016/j. semcancer.2020.05.018.

[8] R.A. Davey, M. Grossmann, Androgen receptor structure, function and biology: from bench to bedside, Clin. Biochem. Rev. 37 (2016) 3-15.

[9] E.C. Bolton, A.Y. So, C. Chaivorapol, C.M. Haqq, H. Li, K.R. Yamamoto, Cell- and gene-specific regulation of primary target genes by the androgen receptor, Genes Dev. 21 (2007) 2005-2017, https://doi.org/10.1101/gad.1564207.

[10] C. Cai, H. Wang, Y. Xu, S. Chen, S.P. Balk, Reactivation of androgen receptorregulated TMPRSS2:ERG gene expression in castration-resistant prostate cancer, Cancer Res. 69 (2009) 6027-6032, https://doi.org/10.1158/0008-5472.CAN-090395.

[11] J. Yu, J. Yu, R.S. Mani, Q. Cao, C.J. Brenner, X. Cao, X. Wang, L. Wu, J. Li, M. Hu, Y. Gong, H. Cheng, B. Laxman, A. Vellaichamy, S. Shankar, Y. Li, S. M. Dhanasekaran, R. Morey, T. Barrette, R.J. Lonigro, S.A. Tomlins, S. Varambally, Z.S. Qin, A.M. Chinnaiyan, An integrated network of androgen receptor, polycomb, and TMPRSS2-ERG gene fusions in prostate cancer progression, Cancer Cell 17 (2010) 443-454, https://doi.org/10.1016/j. ccr.2010.03.018.

[12] E. Nevedomskaya, S.J. Baumgart, B. Haendler, Recent advances in prostate cancer treatment and drug discovery, Int. J. Mol. Sci. 19 (2018), https://doi.org/ 10.3390/ijms19051359.

[13] C.E. Bohl, W. Gao, D.D. Miller, C.E. Bell, J.T. Dalton, Structural basis for antagonism and resistance of bicalutamide in prostate cancer, Proc. Natl. Acad. Sci. U. S. A. 102 (2005) 6201-6206, https://doi.org/10.1073/pnas.0500381102.

[14] W.H. Bisson, A.V. Cheltsov, N. Bruey-Sedano, B. Lin, J. Chen, N. Goldberger, L. T. May, A. Christopoulos, J.T. Dalton, P.M. Sexton, X.K. Zhang, R. Abagyan, Discovery of antiandrogen activity of nonsteroidal scaffolds of marketed drugs, Proc. Natl. Acad. Sci. U. S. A. 104 (2007) 11927-11932, https://doi.org/ 10.1073/pnas.0609752104.

[15] M. Crumbaker, L. Khoja, A.M. Joshua, AR signaling and the PI3K pathway in prostate cancer, Cancers (Basel) 9 (2017), https://doi.org/10.3390/ cancers 9040034.

[16] S.C. Chan, Y. Li, S.M. Dehm, Androgen receptor splice variants activate androgen receptor target genes and support aberrant prostate cancer cell growth independent of canonical androgen receptor nuclear localization signal, J. Biol. Chem. 287 (2012) 19736-19749, https://doi.org/10.1074/jbc.M112.352930.

[17] M. Marín-Aguilera, N. Jiménez, Ò. Reig, R. Montalbo, A.K. Verma, G. Castellano, L. Mengual, I. Victoria, M.V. Pereira, M. Milà-Guasch, S. García-Recio, D. BenítezRibas, R. Cabezón, A. González, M. Juan, A. Prat, B. Mellado, Androgen receptor and its splicing variant 7 expression in peripheral blood mononuclear cells and in circulating tumor cells in metastatic castration-resistant prostate cancer, Cells 9 (2020) 203, https://doi.org/10.3390/cells9010203.

[18] Y. Wang, X. Jiang, F. Feng, W. Liu, H. Sun, Degradation of proteins by PROTACs and other strategies, Acta Pharm. Sin. B 10 (2020) 207-238, https://doi.org/ 10.1016/j.apsb.2019.08.001.

[19] T. Neklesa, L.B. Snyder, R.R. Willard, N. Vitale, J. Pizzano, D.A. Gordon, M. Bookbinder, J. Macaluso, H. Dong, C. Ferraro, G. Wang, J. Wang, C.M. Crews, J. Houston, A.P. Crew, I. Taylor, ARV-110: an oral androgen receptor PROTAC degrader for prostate cancer, J. Clin. Oncol. 37 (2019) 259, https://doi.org/ 10.1200/jco.2019.37.7 suppl.259.

[20] Proof-of-concept with PROTACs in prostate cancer, Cancer Discov. 10 (2020) 1084, https://doi.org/10.1158/2159-8290.CD-NB2020-054.

[21] M. Alyamani, Z. Li, M. Berk, J. Li, J. Tang, S. Upadhyay, R.J. Auchus, N. Sharifi, Steroidogenic metabolism of galeterone reveals a diversity of biochemical activities, Cell Chem. Biol. 24 (2017) 825-832, https://doi.org/10.1016/j. chembiol.2017.05.020, e6.

[22] D.A. Bastos, E.S. Antonarakis, Galeterone for the treatment of advanced prostate cancer: the evidence to date, Drug Des. Devel. Ther. 10 (2016) 2289-2297, https://doi.org/10.2147/DDDT.S93941.

[23] R.R. McKay, L. Werner, M. Fiorillo, J. Roberts, E.I. Heath, G.J. Bubley, R. B. Montgomery, M.E. Taplin, Efficacy of therapies after galeterone in patients with castration-resistant prostate cancer, Clin. Genitourin. Cancer 15 (2017) 463-471, https://doi.org/10.1016/j.clgc.2016.10.006.

[24] Z. Yu, C. Cai, S. Gao, N.I. Simon, H.C. Shen, S.P. Balk, Galeterone prevent androgen receptor binding to chromatin and enhances degradation of mutant androgen receptor, Clin. Cancer Res. 20 (2014) 4075-4085, https://doi.org/ 10.1158/1078-0432.CCR-14-0292.

[25] V.K. Arora, E. Schenkein, R. Murali, S.K. Subudhi, J. Wongvipat, M.D. Balbas, N. Shah, L. Cai, E. Efstathiou, C. Logothetis, D. Zheng, C.L. Sawyers, Glucocorticoid receptor confers resistance to antiandrogens by bypassing androgen receptor blockade, Cell 155 (2013) 1309-1322, https://doi.org/ 10.1016/j.cell.2013.11.012.

[26] J. Hu, Q. Chen, The role of glucocorticoid receptor in prostate cancer progression: from bench to bedside, Int. Urol. Nephrol. 49 (2017) 369-380, https://doi.org/ 10.1007/s11255-016-1476-8.

[27] S.D. Kaffenberger, C.E. Barbieri, Molecular subtyping of prostate cancer, Curr. Opin. Urol. 26 (2016) 213-218, https://doi.org/10.1097/ MOU.0000000000000285. 
[28] S.B. Brown, S.E. Hankinson, Endogenous estrogens and the risk of breast, endometrial, and ovarian cancers, Steroids 99 (2015) 8-10, https://doi.org/ 10.1016/j.steroids.2014.12.013.

[29] Y. Zhou, X. Liu, The role of estrogen receptor beta in breast cancer, Biomark. Res. 8 (2020) 39, https://doi.org/10.1186/s40364-020-00223-2.

[30] S. Yan, P. Dey, Y. Ziegler, X. Jiao, S.H. Kim, J.A. Katzenellenbogen, B. S. Katzenellenbogen, Contrasting activities of estrogen receptor beta isoforms in triple negative breast cancer, Breast Cancer Res. Treat. (2020), https://doi.org/ 10.1007/s10549-020-05948-0.

[31] C. Fougner, H. Bergholtz, J.H. Norum, T. Sørlie, Re-definition of claudin-low as a breast cancer phenotype, Nat. Commun. 11 (2020), https://doi.org/10.1038/ s41467-020-15574-5.

[32] T. Sørlie, C.M. Perou, R. Tibshirani, T. Aas, S. Geisler, H. Johnsen, T. Hastie, M. B. Eisen, M. van de Rijn, S.S. Jeffrey, T. Thorsen, H. Quist, J.C. Matese, P. O. Brown, D. Botstein, P.E. Lønning, A.L. Børresen-Dale, Gene expression patterns of breast carcinomas distinguish tumor subclasses with clinical implications, Proc. Natl. Acad. Sci. U. S. A. 98 (2001) 10869-10874, https://doi.org/10.1073/ pnas.191367098.

[33] S.E. Hankinson, A.H. Eliassen, Circulating sex steroids and breast cancer risk in premenopausal women, Horm. Cancer 1 (2010) 2-10, https://doi.org/10.1007/ s12672-009-0003-0.

[34] J. Ragaz, A. Coldman, Survival impact of adjuvant tamoxifen on competing causes of mortality in breast cancer survivors, with analysis of mortality from contralateral breast cancer, cardiovascular events, endometrial cancer, and thromboembolic episodes, J. Clin. Oncol. 16 (1998), https://doi.org/10.1200/ JCO.1998.16.6.2018, 2018-24.

[35] A. Howell, J.F.R. Robertson, J.Q. Albano, A. Aschermannova, L. Mauriac, U. R. Kleeberg, I. Vergote, B. Erikstein, A. Webster, C. Morris, Fulvestrant, formerly ICI 182,780 , is as effective as anastrozole in postmenopausal women with advanced breast cancer progressing after prior endocrine treatment, J. Clin. Oncol. 20 (2002), https://doi.org/10.1200/JCO.2002.10.057, 3396-403.

[36] M.R. Nathan, P. Schmid, A review of fulvestrant in breast cancer, Oncol. Ther. 5 (2017) 17-29, https://doi.org/10.1007/s40487-017-0046-2.

[37] I.E. Smith, M. Dowsett, Aromatase inhibitors in breast cancer, N. Engl. J. Med. 348 (2003) 2431-2442, https://doi.org/10.1056/NEJMra023246.

[38] M.D. Brooks, M.L. Burness, M.S. Wicha, Therapeutic implications of cellular heterogeneity and plasticity in breast cancer, Cell Stem Cell 17 (2015) 71-260, https://doi.org/10.1016/j.stem.2015.08.014.

[39] C.X. Ma, T. Reinert, I. Chmielewska, M.J. Ellis, Mechanisms of aromatase inhibitor resistance, Nat. Rev. Cancer 15 (2015) 261-275, https://doi.org/ 10.1038/nrc3920.

[40] H. Pan, R. Gray, J. Braybrooke, C. Davies, C. Taylor, P. McGale, R. Peto, K. I. Pritchard, J. Bergh, M. Dowsett, D.F. Hayes, 20-year risks of breast-cancer recurrence after stopping endocrine therapy at 5 years, N. Engl. J. Med. 377 (2017) 1836-1846, https://doi.org/10.1056/NEJMoa1701830.

[41] F. Bertucci, C.K.Y. Ng, A. Patsouris, N. Droin, S. Piscuoglio, N. Carbuccia, J. C. Soria, A.T. Dien, Y. Adnani, M. Kamal, S. Garnier, G. Meurice, M. Jimenez, S. Dogan, B. Verret, M. Chaffanet, T. Bachelot, M. Campone, C. Lefeuvre, H. Bonnefoi, F. Dalenc, A. Jacquet, M.R. De Filippo, N. Babbar, D. Birnbaum, T. Filleron, C. Le Tourneau, F. André, Genomic characterization of metastatic breast cancers, Nature 569 (2019) 560-564, https://doi.org/10.1038/s41586019-1056-z.

[42] B. Verret, J. Cortes, T. Bachelot, F. Andre, M. Arnedos, Efficacy of PI3K inhibitors in advanced breast cancer, Ann. Oncol. Off. J. Eur. Soc. Med. Oncol. 30 (Suppl. 10) (2019) x12-x20, https://doi.org/10.1093/annonc/mdz381.

[43] D.A. Olsen, T. Bechmann, B. Østergaard, P.A. Wamberg, E.H. Jakobsen, I. Brandslund, Increased concentrations of growth factors and activation of the EGFR system in breast cancer, Clin. Chem. Lab. Med. 50 (2012) 1809-1818, https://doi.org/10.1515/cclm-2011-0823.

[44] T. Zhang, F. Feng, Y. Yao, L. Qi, J. Tian, C. Zhou, S. Dong, X. Wang, C. Sun, Efficacy and acceptability of neoadjuvant endocrine therapy in patients with hormone receptor-positive breast cancer: a network meta-analysis, J. Cell. Physiol. 234 (2019) 12393-12403, https://doi.org/10.1002/jcp.28068.

[45] K. Tryfonidis, G. Basaran, J. Bogaerts, M. Debled, L. Dirix, J.C. Thery, V.C.G. TjanHeijnen, D. Van Den Weyngaert, T. Cufer, M. Piccart, D. Cameron, A European Organisation for Research and Treatment of Cancer randomized, double-blind, placebo-controlled, multicentre phase II trial of anastrozole in combination with gefitinib or placebo in hormone receptor-positive advanced breast cancer (NCT00066378), Eur. J. Cancer 53 (2016) 144-154, https://doi.org/10.1016/j. ejca.2015.10.012.

[46] S. Pancholi, R. Ribas, N. Simigdala, E. Schuster, J. Nikitorowicz-Buniak, A. Ressa, Q. Gao, M.F. Leal, A. Bhamra, A. Thornhill, L. Morisset, E. Montaudon, L. Sourd, M. Fitzpatrick, M. Altelaar, S.R. Johnston, E. Marangoni, M. Dowsett, L.A. Martin, Tumour kinome re-wiring governs resistance to palbociclib in oestrogen receptor positive breast cancers, highlighting new therapeutic modalities, Oncogene 39 (2020) 4781-4797, https://doi.org/10.1038/s41388-020-1284-6.

[47] A. Basudan, N. Priedigkeit, R.J. Hartmaier, E.S. Sokol, A. Bahreini, R.J. Watters, M.M. Boisen, R. Bhargava, K.R. Weiss, M.M. Karsten, C. Denkert, J.-U. Blohmer, J. P. Leone, R.L. Hamilton, A.M. Brufsky, E. Elishaev, P.C. Lucas, A.V. Lee, S. Oesterreich, Frequent ESR1 and CDK pathway copy-number alterations in metastatic breast cancer, Mol. Cancer Res. 17 (2019) 457-468, https://doi.org/ 10.1158/1541-7786.MCR-18-0946.

[48] F. Holst, P.R. Stahl, C. Ruiz, O. Hellwinkel, Z. Jehan, M. Wendland, A. Lebeau, L. Terracciano, K. Al-Kuraya, F. Jänicke, G. Sauter, R. Simon, Estrogen receptor alpha (ESR1) gene amplification is frequent in breast cancer, Nat. Genet. 39 (2007) 655-660, https://doi.org/10.1038/ng2006.
[49] S.W. Fanning, C.G. Mayne, V. Dharmarajan, K.E. Carlson, T.A. Martin, S. J. Novick, W. Toy, B. Green, S. Panchamukhi, B.S. Katzenellenbogen, E. Tajkhorshid, P.R. Griffin, Y. Shen, S. Chandarlapaty, J.A. Katzenellenbogen, G. L. Greene, Estrogen receptor alpha somatic mutations Y537S and D538G confer breast cancer endocrine resistance by stabilizing the activating function-2 binding conformation, Elife 5 (2016), https://doi.org/10.7554/eLife.12792.

[50] R. Jeselsohn, J.S. Bergholz, M. Pun, M. Cornwell, W. Liu, A. Nardone, T. Xiao, W. Li, X. Qiu, G. Buchwalter, A. Feiglin, K. Abell-Hart, T. Fei, P. Rao, H. Long, N. Kwiatkowski, T. Zhang, N. Gray, D. Melchers, R. Houtman, X.S. Liu, O. Cohen, N. Wagle, E.P. Winer, J. Zhao, M. Brown, Allele-specific chromatin recruitment and therapeutic vulnerabilities of ESR1 activating mutations, Cancer Cell 33 (2018) 173-186, https://doi.org/10.1016/j.ccell.2018.01.004, e5.

[51] J. Park, Y.J. Lee, Hypoxia induced phosphorylation of estrogen receptor at serine 118 in the absence of ligand, J. Steroid Biochem. Mol. Biol. 174 (2017) 146-152, https://doi.org/10.1016/j.jsbmb.2017.08.013.

[52] M. Anbalagan, B.G. Rowan, Estrogen receptor alpha phosphorylation and its functional impact in human breast cancer, Mol. Cell. Endocrinol. 418 Pt 3 (2015) 72-264, https://doi.org/10.1016/j.mce.2015.01.016.

[53] O. Iriondo, M. Rábano, G. Domenici, O. Carlevaris, J.A. López-Ruiz, I. Zabalza, E. Berra, M. dM Vivanco, Distinct breast cancer stem/progenitor cell populations require either HIF1 $\alpha$ or loss of PHD3 to expand under hypoxic conditions, Oncotarget 6 (2015) 31721-31739, https://doi.org/10.18632/oncotarget.5564.

[54] A. Jögi, A. Ehinger, L. Hartman, S. Alkner, Expression of HIF-1 $\alpha$ is related to a poor prognosis and tamoxifen resistance in contralateral breast cancer, PLoS One 14 (2019) e0226150, https://doi.org/10.1371/journal.pone.0226150.

[55] M. Piva, G. Domenici, O. Iriondo, M. Rábano, B.M. Simões, V. Comaills, I. Barredo, J.A. López-Ruiz, I. Zabalza, R. Kypta, M.D.M. Vivanco, Sox2 promotes tamoxifen resistance in breast cancer cells, EMBO Mol. Med. 6 (2014) 66-79, https://doi.org/10.1002/emmm.201303411.

[56] X. Cui, R. Schiff, G. Arpino, C.K. Osborne, A.V. Lee, Biology of progesterone receptor loss in breast cancer and its implications for endocrine therapy, J. Clin. Oncol. 23 (2005) 7721-7735, https://doi.org/10.1200/JCO.2005.09.004.

[57] D. Chi, H. Singhal, L. Li, T. Xiao, W. Liu, M. Pun, R. Jeselsohn, H. He, E. Lim, R. Vadhi, P. Rao, H. Long, J. Garber, M. Brown, Estrogen receptor signaling is reprogrammed during breast tumorigenesis, Proc. Natl. Acad. Sci. U. S. A. 116 (2019) 11437-11443, https://doi.org/10.1073/pnas.1819155116.

[58] M. Umetani, H. Domoto, A.K. Gormley, I.S. Yuhanna, C.L. Cummins, N.B. Javitt, K.S. Korach, P.W. Shaul, D.J. Mangelsdorf, 27-Hydroxycholesterol is an endogenous SERM that inhibits the cardiovascular effects of estrogen, Nat. Med. 13 (2007) 92-1185, https://doi.org/10.1038/nm1641.

[59] C.D. DuSell, M. Umetani, P.W. Shaul, D.J. Mangelsdorf, D.P. McDonnell, 27Hydroxycholesterol is an endogenous selective estrogen receptor modulator, Mol. Endocrinol. 22 (2008) 65-77, https://doi.org/10.1210/me.2007-0383.

[60] L. Cedó, S.T. Reddy, E. Mato, F. Blanco-Vaca, J.C. Escolà-Gil, HDL and LDL: potential new players in breast cancer development, J. Clin. Med. 8 (2019) 853, https://doi.org/10.3390/jcm8060853.

[61] H. Clayton, I. Titley, Md.M. Vivanco, Growth and differentiation of progenitor/ stem cells derived from the human mammary gland, Exp. Cell Res. 297 (2004) 444-460, https://doi.org/10.1016/j.yexcr.2004.03.029.

[62] C. Ginestier, M.H. Hur, E. Charafe-Jauffret, F. Monville, J. Dutcher, M. Brown, J. Jacquemier, P. Viens, C.G. Kleer, S. Liu, A. Schott, D. Hayes, D. Birnbaum, M. S. Wicha, G. Dontu, ALDH1 is a marker of normal and malignant human mammary stem cells and a predictor of poor clinical outcome, Cell Stem Cell 1 (2007) 555-567, https://doi.org/10.1016/j.stem.2007.08.014.

[63] M. Al-Hajj, M.S. Wicha, A. Benito-Hernandez, S.J. Morrison, M.F. Clarke, Prospective identification of tumorigenic breast cancer cells, Proc. Natl. Acad. Sci. U. S. A. 100 (2003) 3983-3988, https://doi.org/10.1073/pnas.0530291100.

[64] B.M. Simões, M.D. Vivanco, Cancer stem cells in the human mammary gland and regulation of their differentiation by estrogen, Future Oncol. 7 (2011) 995-1006, https://doi.org/10.2217/fon.11.80.

[65] M.G. Scioli, G. Storti, F. D'amico, P. Gentile, G. Fabbri, V. Cervelli, A. Orlandi, The role of breast cancer stem cells as a prognostic marker and a target to improve the efficacy of breast cancer therapy, Cancers (Basel) 11 (2019), https:// doi.org/10.3390/cancers11071021.

[66] B.M. Simões, M. Piva, O. Iriondo, V. Comaills, J.A. López-Ruiz, I. Zabalza, J. A. Mieza, O. Acinas, M.D.M. Vivanco, Effects of estrogen on the proportion of stem cells in the breast, Breast Cancer Res. Treat. 129 (2011) 23-35, https://doi. org/10.1007/s10549-010-1169-4.

[67] Y. Yin, C.-M. Xie, H. Li, M. Tan, G. Chen, R. Schiff, X. Xiong, Y. Sun, The FBXW2MSX2-SOX2 axis regulates stem cell property and drug resistance of cancer cells, Proc. Natl. Acad. Sci. U. S. A. 116 (2019) 20528-20538, https://doi.org/ 10.1073/pnas.1905973116.

[68] G. Domenici, I. Aurrekoetxea-Rodríguez, B.M. Simões, M. Rábano, S.Y. Lee, J. S. Millán, V. Comaills, E. Oliemuller, J.A. López-Ruiz, I. Zabalza, B.A. Howard, R. M. Kypta, Md.M. Vivanco, A Sox2-Sox9 signalling axis maintains human breast luminal progenitor and breast cancer stem cells, Oncogene 38 (2019) 3151-3169, https://doi.org/10.1038/s41388-018-0656-7.

[69] B. ózsvári, F. Sotgia, M.P. Lisanti, First-in-class candidate therapeutics that target mitochondria and effectively prevent cancer cell metastasis: mitoriboscins and TPP compounds, Aging (Albany. NY) 12 (2020) 10162-10179, https://doi.org/ 10.18632/aging.103336.

[70] S.D. Conzen, Nuclear receptors and breast cancer, Mol. Endocrinol. 22 (2008) 2215-2228, https://doi.org/10.1210/me.2007-0421.

[71] L.S. Schwartzberg, D.A. Yardley, A.D. Elias, M. Patel, P. Lorusso, H.A. Burris, A. Gucalp, A.C. Peterson, M.E. Blaney, J.L. Steinberg, J.A. Gibbons, T.A. Traina, A phase I/Ib study of enzalutamide alone and in combination with endocrine 
therapies in women with advanced breast cancer, Clin. Cancer Res. 23 (2017) 4046-4054, https://doi.org/10.1158/1078-0432.CCR-16-2339.

[72] S. Timmermans, J. Souffriau, C. Libert, A general introduction to glucocorticoid biology, Front. Immunol. 10 (2019) 1545, https://doi.org/10.3389/ fimmu.2019.01545.

[73] L. Escoter-Torres, G. Caratti, A. Mechtidou, J. Tuckermann, N.H. Uhlenhaut, S. Vettorazzi, Fighting the fire: mechanisms of inflammatory gene regulation by the glucocorticoid receptor, Front. Immunol. 10 (2019) 1859, https://doi.org/ 10.3389/fimmu. 2019.01859.

[74] J. Vandewalle, A. Luypaert, K. De Bosscher, C. Libert, Therapeutic mechanisms of glucocorticoids, Trends Endocrinol. Metab. 29 (2018) 42-54, https://doi.org/ 10.1016/j.tem.2017.10.010.

[75] D.W. Cain, J.A. Cidlowski, Immune regulation by glucocorticoids, Nat. Rev. Immunol. 17 (2017) 233-247, https://doi.org/10.1038/nri.2017.1.

[76] M.A. Pufall, Glucocorticoids and cancer, in: J.-C. Wang, C. Harris (Eds.), Glucocorticoid Signal. From Mol. to Mice to Man, Springer Science+Business Media, New York, 2015, pp. 315-333.

[77] K.T. Lin, L.H. Wang, New dimension of glucocorticoids in cancer treatment, Steroids 111 (2016) 84-88, https://doi.org/10.1016/j.steroids.2016.02.019.

[78] T.H. Truong, C.A. Lange, Deciphering steroid receptor crosstalk in hormonedriven cancers, Endocrinology 159 (2018) 3897-3907, https://doi.org/10.1210/ en.2018-00831.

[79] A. Jiménez-Panizo, P. Pérez, A.M. Rojas, P. Fuentes-Prior, E. Estébanez-Perpiñá, Non-canonical dimerization of the androgen receptor and other nuclear receptors: implications for human disease, Endocr. Relat. Cancer 26 (2019) R479-R497, https://doi.org/10.1530/ERC-19-0132.

[80] I.V. Budunova, D. Kowalczyk, P. Pérez, Y.J. Yao, J.L. Jorcano, T.J. Slaga, Glucocorticoid receptor functions as a potent suppressor of mouse skin carcinogenesis, Oncogene 22 (2003) 3279-3287, https://doi.org/10.1038/sj. onc. 1206383.

[81] V. Latorre, L.M. Sevilla, A. Sanchis, P. Pérez, Selective ablation of glucocorticoid receptor in mouse keratinocytes increases susceptibility to skin tumorigenesis, J. Invest. Dermatol. 133 (2013) 2771-2779, https://doi.org/10.1038/ jid.2013.255.

[82] D. Chebotaev, A. Yemelyanov, I. Budunova, The mechanisms of tumor suppresso effect of glucocorticoid receptor in skin. Mol. Carcinog., Mol Carcinog, 2007, pp. 732-740, https://doi.org/10.1002/mc.20349.

[83] N. Sundahl, J. Bridelance, C. Libert, K. De Bosscher, I.M. Beck, Selective glucocorticoid receptor modulation: new directions with non-steroidal scaffolds, Pharmacol. Ther. 152 (2015) 28-41, https://doi.org/10.1016/j. pharmthera.2015.05.001.

[84] T.R. Flint, D.T. Fearon, T. Janowitz, Connecting the metabolic and immune responses to cancer, Trends Mol. Med. 23 (2017) 451-464, https://doi.org/ 10.1016/j.molmed.2017.03.001.

[85] S. Sengupta, B. Wasylyk, Physiological and pathological consequences of the interactions of the p53 tumor suppressor with the glucocorticoid, androgen, and estrogen receptors. Ann. N. Y. Acad. Sci., New York Academy of Sciences, 2004, pp. 54-71, https://doi.org/10.1196/annals.1321.005.

[86] M.H. Aziz, H. Shen, C.G. Maki, Glucocorticoid receptor activation inhibits p53induced apoptosis of MCF10Amyc cells via induction of protein kinase C $\varepsilon$, J. Biol. Chem. 287 (2012) 29825-29836, https://doi.org/10.1074/jbc.M112.393256.

[87] P. Fan, D.R. Siwak, B. Abderrahman, F.A. Agboke, S. Yerrum, V.C. Jordan, Suppression of nuclear factor-kB by glucocorticoid receptor blocks estrogeninduced apoptosis in estrogen-deprived breast cancer cells, Mol. Cancer Ther. 18 (2019) 1684-1695, https://doi.org/10.1158/1535-7163.MCT-18-1363.

[88] J. Ling, R. Kumar, Crosstalk between NFkB and glucocorticoid signaling: a potential target of breast cancer therapy, Cancer Lett. 322 (2012) 119-126, https://doi.org/10.1016/j.canlet.2012.02.033.

[89] W. Wu, T. Pew, M. Zou, D. Pang, S.D. Conzen, Glucocorticoid receptor-induced MAPK phosphatase-1 (MPK-1) expression inhibits paclitaxel-associated MAPK activation and contributes to breast cancer cell survival, J. Biol. Chem. 280 (2005) 4117-4124, https://doi.org/10.1074/jbc.M411200200.

[90] M. Vilasco, L. Communal, N. Mourra, A. Courtin, P. Forgez, A. Gompel, Glucocorticoid receptor and breast cancer, Breast Cancer Res. Treat. 130 (2011) 1-10, https://doi.org/10.1007/s10549-011-1689-6.

[91] E. Ayroldi, L. Cannarile, D.V. Delfino, C. Riccardi, A dual role for glucocorticoidinduced leucine zipper in glucocorticoid function: tumor growth promotion or suppression? Review-article, Cell Death Dis. 9 (2018), https://doi.org/10.1038/ s41419-018-0558-1.

[92] A. Yemelyanov, J. Czwornog, D. Chebotaev, A. Karseladze, E. Kulevitch, X. Yang, I. Budunova, Tumor suppressor activity of glucocorticoid receptor in the prostate, Oncogene 26 (2007) 1885-1896, https://doi.org/10.1038/sj.onc.1209991.

[93] L.C. Matthews, A.A. Berry, D.J. Morgan, T.M. Poolman, K. Bauer, F. Kramer, D. G. Spiller, R.V. Richardson, K.E. Chapman, S.N. Farrow, M.R. Norman, A.J. K. Williamson, A.D. Whetton, S.S. Taylor, J.P. Tuckermann, M.R.H. White, D. W. Ray, Glucocorticoid receptor regulates accurate chromosome segregation and is associated with malignancy, Proc. Natl. Acad. Sci. U. S. A. 112 (2015) 5479-5484, https://doi.org/10.1073/pnas.1411356112.

[94] M. Voisin, P. De Medina, A. Mallinger, F. Dalenc, E. Huc-Claustre, J. Leignadier, N. Serhan, R. Soules, G. Ségala, A. Mougel, E. Noguer, L. Mhamdi, E. Bacquié, L. Iuliano, C. Zerbinati, M. Lacroix-Triki, L. Chaltiel, T. Filleron, V. Cavaillès, T. Al Saati, P. Rochaix, R. Duprez-Paumier, C. Franchet, L. Ligat, F. Lopez, M. Record, M. Poirot, S. Silvente-Poirot, Identification of a tumor-promoter cholesterol metabolite in human breast cancers acting through the glucocorticoid receptor, Proc. Natl. Acad. Sci. U. S. A. 114 (2017) E9346-E9355, https://doi.org/ 10.1073/pnas.1707965114.
[95] S. Silvente-Poirot, F. Dalenc, M. Poirot, The effects of cholesterol-derived oncometabolites on nuclear receptor function in cancer, Cancer Res. 78 (2018) 4803-4808, https://doi.org/10.1158/0008-5472.CAN-18-1487.

[96] P.J. Davis, H.-Y. Lin, A.A. Hercbergs, K.A. Keating, S.A. Mousa, How thyroid hormone works depends on cell type, receptor type, and hormone analogue: implications in cancer growth, Discov. Med. 27 (2019) 111-117.

[97] A. Pascual, A. Aranda, Thyroid hormone receptors, cell growth and differentiation, Biochim. Biophys. Acta - Gen. Subj. 1830 (2013) 3908-3916, https://doi.org/10.1016/j.bbagen.2012.03.012.

[98] A. Aranda, O. Martínez-Iglesias, L. Ruiz-Llorente, V. García-Carpizo, A. Zambrano, Thyroid receptor: roles in cancer, Trends Endocrinol. Metab. 20 (2009) 318-324, https://doi.org/10.1016/j.tem.2009.03.011.

[99] S.Y. Cheng, J.L. Leonard, P.J. Davis, Molecular aspects of thyroid hormone actions, Endocr. Rev. 31 (2010) 139-170, https://doi.org/10.1210/er.20090007.

[100] C. Barlow, B. Meister, M. Lardelli, U. Lendahl, B. Vennström, Thyroid abnormalities and hepatocellular carcinoma in mice transgenic for v-erbA, EMBO J. 13 (1994) 4241-4250, https://doi.org/10.1002/j.1460-2075.1994.tb06744.x.

[101] X.G. Zhu, L. Zhao, M.C. Willingham, S.Y. Cheng, Thyroid hormone receptors are tumor suppressors in a mouse model of metastatic follicular thyroid carcinoma, Oncogene 29 (2010) 1909-1919, https://doi.org/10.1038/onc.2009.476.

[102] C.J. Guigon, D.W. Kim, M.C. Willingham, S.Y. Cheng, Mutation of thyroid hormone receptor-B in mice predisposes to the development of mammary tumors, Oncogene 30 (2011) 3384-3390, https://doi.org/10.1038/onc.2011.50.

[103] O. Martínez-Iglesias, S. Garcia-Silva, S.P. Tenbaum, J. Regadera, F. Larcher, J. M. Paramio, B. Vennström, A. Aranda, Thyroid hormone receptor $\beta 1$ acts as a potent suppressor of tumor invasiveness and metastasis, Cancer Res. 69 (2009) 501-509, https://doi.org/10.1158/0008-5472.CAN-08-2198.

[104] A. Francavilla, B.I. Carr, A. Azzarone, L. Polimeno, Z. Wang, D.H. Van Thiel, V. Subbotin, J.G. Prelich, T.E. Starzl, Hepatocyte proliferation and gene expression induced by triiodothyronine in vivo and in vitro, Hepatology 20 (1994) 1237-1241, https://doi.org/10.1002/hep.1840200521.

[105] R. López-Fontal, M. Zeini, P.G. Través, M. Gómez-Ferrería, A. Aranda, G.T. Sáez, C. Cerdá, P. Martín-Sanz, S. Hortelano, L. Boscá, Mice lacking thyroid hormone receptor $\beta$ show enhanced apoptosis and delayed liver commitment for proliferation after partial hepatectomy, PLoS One 5 (2010), https://doi.org/ 10.1371/journal.pone.0008710.

[106] G.M. Ledda-Columbano, A. Perra, R. Loi, H. Shinozuka, A. Columbano, Cell proliferation induced by triiodothyronine in rat liver is associated with nodule regression and reduction of hepatocellular carcinomas, Cancer Res, 60 (2000).

[107] A. Reddy, C. Dash, A. Leerapun, T.A. Mettler, L.M. Stadheim, K.N. Lazaridis, R. O. Roberts, L.R. Roberts, Hypothyroidism: a possible risk factor for liver cancer in patients with no known underlying cause of liver disease, Clin. Gastroenterol. Hepatol. 5 (2007) 118-123, https://doi.org/10.1016/j.coh.2006.07.011.

[108] C. Frau, R. Loi, A. Petrelli, A. Perra, S. Menegon, M.A. Kowalik, S. Pinna, V. P. Leoni, F. Fornari, L. Gramantieri, G.M. Ledda-Columbano, S. Giordano, A. Columbano, Local hypothyroidism favors the progression of preneoplastic lesions to hepatocellular carcinoma in rats, Hepatology 61 (2015) 249-259, https://doi.org/10.1002/hep.27399.

[109] E. Kress, S. Skah, M. Sirakov, J. Nadjar, N. Gadot, J.Y. Scoazec, J. Samarut, M. Plateroti, Cooperation between the thyroid hormone receptor TR $\alpha 1$ and the WNT pathway in the induction of intestinal tumorigenesis, Gastroenterology 138 (2010) 74-1863, https://doi.org/10.1053/j.gastro.2010.01.041.

[110] S. Markowitz, M. Haut, T. Stellato, C. Gerbic, K. Molkentin, Expression of the ErbA- $\beta$ class of thyroid hormone receptors is selectively lost in human colon carcinoma, J. Clin. Invest. 84 (1989) 1683-1687, https://doi.org/10.1172/ JCI114349.

[111] T.T. Hörkkö, K. Tuppurainen, S.M. George, P. Jernvall, T.J. Karttunen, M. J. Mäkinen, Thyroid hormone receptor $\beta 1$ in normal colon and colorectal cancerassociation with differentiation, polypoid growth type and K-ras mutations, Int. J. Cancer 118 (2006) 1653-1659, https://doi.org/10.1002/ijc.21556.

[112] K.J. Jerzak, J.G. Cockburn, S.K. Dhesy-Thind, G.R. Pond, K.I. Pritchard, S. NofechMozes, P. Sun, S.A. Narod, A. Bane, Thyroid hormone receptor beta-1 expression in early breast cancer: a validation study, Breast Cancer Res. Treat. 171 (2018) 709-717, https://doi.org/10.1007/s10549-018-4844-5.

[113] K.J. Jerzak, J. Cockburn, G.R. Pond, K.I. Pritchard, S.A. Narod, S.K. Dhesy-Thind, A. Bane, Thyroid hormone receptor $\alpha$ in breast cancer: prognostic and therapeutic implications, Breast Cancer Res. Treat. 149 (2015) 293-301, https://doi.org/ 10.1007/s10549-014-3235-9.

[114] M. Cristofanilli, Y. Yamamura, S.W. Kau, T. Bevers, S. Strom, M. Patangan, L. Hsu, S. Krishnamurthy, R.L. Theriault, G.N. Hortobagyi, Thyroid hormone and breast carcinoma: primary hypothyroidism is associated with a reduced incidence of primary breast carcinoma, Cancer 103 (2005) 1122-1128, https://doi.org/ 10.1002/cncr.20881.

[115] O. Martínez-Iglesias, S. García-Silva, J. Regadera, A. Aranda, Hypothyroidism enhances tumor invasiveness and metastasis development, PLoS One 4 (2009), https://doi.org/10.1371/journal.pone.0006428.

[116] M. Collado, M. Serrano, Senescence in tumours: evidence from mice and humans, Nat. Rev. Cancer 10 (2010) 51-57, https://doi.org/10.1038/nrc2772.

[117] A. Zambrano, V. García-Carpizo, M.E. Gallardo, R. Villamuera, M.A. GómezFerrería, A. Pascual, N. Buisine, L.M. Sachs, R. Garesse, A. Aranda, The thyroid hormone receptor $\beta$ induces DNA damage and premature senescence, J. Cell Biol. 204 (2014) 129-146, https://doi.org/10.1083/jcb.201305084.

[118] L. Ruiz-Llorente, S. Ardila-González, L.F. Fanjul, O. Martínez-Iglesias, A. Aranda, microRNAs 424 and 503 are mediators of the anti-proliferative and anti-invasive 
action of the thyroid hormone receptor beta, Oncotarget 5 (2014) 2918-2933, https://doi.org/10.18632/oncotarget.1577.

[119] E. Alonso-Merino, R.M. Orozco, L. Ruíz-Llorente, O.A. Martínez-Iglesias, J. P. Velasco-Martín, A. Montero-Pedrazuela, L. Fanjul-Rodríguez, C. ContrerasJurado, J. Regadera, A. Aranda, Thyroid hormones inhibit TGF- $\beta$ signaling and attenuate fibrotic responses, Proc. Natl. Acad. Sci. U. S. A. 113 (2016) E3451-E3460, https://doi.org/10.1073/pnas.1506113113.

[120] O.A. Martínez-Iglesias, E. Alonso-Merino, S. Gómez-Rey, J.P. Velasco-Martín, R. M. Orozco, E. Luengo, R.G. Martín, I. Ibáñez De Cáceres, A.F. Fernández, M. F. Fraga, P. González-Peramato, C. Varona, J. Palacios, J. Regadera, A. Aranda, Autoregulatory loop of nuclear corepressor 1 expression controls invasion, tumor growth, and metastasis, Proc. Natl. Acad. Sci. U. S. A. 113 (2016) E328-E337, https://doi.org/10.1073/pnas.1520469113.

[121] O. Martínez-Iglesias, D. Olmeda, E. Alonso-Merino, S. Gómez-Rey, A.M. GonzálezLópez, E. Luengo, M.S. Soengas, J. Palacios, J. Regadera, A. Aranda, The nuclear corepressor 1 and the thyroid hormone receptor $\beta$ suppress breast tumor lymphangiogenesis, Oncotarget 7 (2016) 78971-78984, https://doi.org/ 10.18632/oncotarget.12978.

[122] A.J. Minn, G.P. Gupta, P.M. Siegel, P.D. Bos, W. Shu, D.D. Giri, A. Viale, A B. Olshen, W.L. Gerald, J. Massagué, Genes that mediate breast cancer metastasis to lung, Nature 436 (2005) 518-524, https://doi.org/10.1038/nature03799.

[123] P.J. Stephens, P.S. Tarpey, H. Davies, P. Van Loo, C. Greenman, D.C. Wedge, S. Nik-Zainal, S. Martin, I. Varela, G.R. Bignell, L.R. Yates, E. Papaemmanuil, D. Beare, A. Butler, A. Cheverton, J. Gamble, J. Hinton, M. Jia, A. Jayakumar, D. Jones, C. Latimer, K.W. Lau, S. McLaren, D.J. McBride, A. Menzies, L. Mudie, K. Raine, R. Rad, M.S. Chapman, J. Teague, D. Easton, A. Langerød, R. Karesen, E. Schlichting, B. Naume, T. Sauer, L. Ottestad, M.T.M. Lee, C.Y. Shen, B.T.K. Tee, B.W. Huimin, A. Broeks, A.C. Vargas, G. Turashvili, J. Martens, A. Fatima, P. Miron, S.F. Chin, G. Thomas, S. Boyault, O. Mariani, S.R. Lakhani, M. Van De Vijver, L. Van't Veer, J. Foekens, C. Desmedt, C. Sotiriou, A. Tutt, C. Caldas, J. S. Reis-Filho, S.A.J.R. Aparicio, A.V. Salomon, A.L. Børresen-Dale, A. L. Richardson, P.J. Campbell, P.A. Futreal, M.R. Stratton, The landscape of cance genes and mutational processes in breast cancer, Nature 486 (2012) 400-404, https://doi.org/10.1038/nature11017.

[124] J.E. Visvader, G.J. Lindeman, Cancer stem cells in solid tumours: accumulating evidence and unresolved questions, Nat. Rev. Cancer 8 (2008) 755-768, https: doi.org/10.1038/nrc2499.

[125] I. López-Mateo, E. Alonso-Merino, C. Suarez-Cabrera, J.W. Park, S.Y. Cheng S. Alemany, J.M. Paramio, A. Aranda, Thyroid hormone receptor $\beta$ inhibits self renewal capacity of breast cancer stem cells, Thyroid 30 (2020) 116-132, https:// doi.org/10.1089/thy.2019.0175.

[126] V. Duong, C. Rochette-Egly, The molecular physiology of nuclear retinoic acid receptors. From health to disease, Biochim. Biophys. Acta - Mol. Basis Dis. 1812 (2011) 1023-1031, https://doi.org/10.1016/j.bbadis.2010.10.007.

[127] L. Altucci, M.D. Leibowitz, K.M. Ogilvie, A.R. de Lera, H. Gronemeyer, RAR and RXR modulation in cancer and metabolic disease, Nat. Rev. Drug Discov. 6 (2007) 793-810, https://doi.org/10.1038/nrd2397.

[128] M. Liu, A. Iavarone, L.P. Freedman, Transcriptional activation of the human p21 (WAF1/CIP1) gene by retinoic acid receptor. Correlation with retinoid induction of U937 cell differentiation, J. Biol. Chem. 271 (1996) 31723-31728, https://doi. org $/ 10.1074 / j b c .271,49.31723$.

[129] A.M. Jiménez-Lara, N. Clarke, L. Altucci, H. Gronemeyer, Retinoic-acid-induced apoptosis in leukemia cells, Trends Mol. Med. 10 (2004) 15-508, https://doi.org/ 10.1016/j.molmed.2004.08.006.

[130] O. di Martino, J.S. Welch, Retinoic acid receptors in acute myeloid leukemia therapy, Cancers (Basel) 11 (2019), https://doi.org/10.3390/cancers11121915.

[131] F.F. Ferrara, F. Fazi, A. Bianchini, F. Padula, V. Gelmetti, S. Minucci, M. Mancini, P.G. Pelicci, F. Lo Coco, C. Nervi, Histone deacetylase-targeted treatment restore retinoic acid signaling and differentiation in acute myeloid leukemia, Cancer Res. 61 (2001) 2-7.

[132] N. Bushue, Y.J.Y. Wan, Retinoid pathway and cancer therapeutics, Adv. Drug Deliv. Rev. 62 (2010) 98-1285, https://doi.org/10.1016/j.addr.2010.07.003.

[133] X.C. Xu, Tumor-suppressive activity of retinoic acid receptor- $\beta$ in cancer, Cance Lett. 253 (2007) 14-24, https://doi.org/10.1016/j.canlet.2006.11.019.

[134] A. Leder, A. Kuo, R.D. Cardiff, E. Sinn, P. Leder, v-Ha-ras transgene abrogates the initiation step in mouse skin tumorigenesis: effects of phorbol esters and retinoic acid, Proc. Natl. Acad. Sci. U. S. A. 87 (1990) 82-9178, https://doi.org/10.1073/ pnas.87.23.9178.

[135] L. Costantini, R. Molinari, B. Farinon, N. Merendino, Retinoic acids in the treatment of most lethal solid cancers, J. Clin. Med. 9 (2020) 360, https://doi. org/10.3390/jcm9020360.

[136] I.P. Uray, E. Dmitrovsky, P.H. Brown, Retinoids and rexinoids in cancer prevention: from laboratory to clinic, Semin. Oncol. 43 (2016) 49-64, https://doi org/10.1053/j.seminoncol.2015.09.002.

[137] A. Papi, S. De Carolis, S. Bertoni, G. Storci, V. Sceberras, D. Santini, C. Ceccarelli, M. Taffurelli, M. Orlandi, M. Bonafé, PPAR $\gamma$ and RXR ligands disrupt the inflammatory cross-talk in the hypoxic breast cancer stem cells niche, J. Cell. Physiol. 229 (2014) 1595-1606, https://doi.org/10.1002/jcp.24601.

[138] M. Cao, D.B. Royce, R. Risingsong, C.R. Williams, M.B. Sporn, K.T. Liby, The rexinoids LG100268 and LG101506 inhibit inflammation and suppress lung carcinogenesis in A/J mice, Cancer Prev. Res. Phila. (Phila) 9 (2016) 105-114, https://doi.org/10.1158/1940-6207.CAPR-15-0325.

[139] R. Ocadiz-Delgado, E. Castaneda-Saucedo, A.K. Indra, R. Hernandez-Pando, P. Gariglio, Impaired cervical homeostasis upon selective ablation of RXR $\alpha$ in epithelial cells, Genesis 46 (2008) 19-28, https://doi.org/10.1002/dvg.20357.
[140] J. Huang, W.C. Powell, A.C. Khodavirdi, J. Wu, T. Makita, R.D. Cardiff, M B. Cohen, H.M. Sucov, P. Roy-Burman, Prostatic intraepithelial neoplasia in mice with conditional disruption of the retinoid $\mathrm{X}$ receptor $\alpha$ allele in the prostate epithelium, Cancer Res. 62 (2002).

[141] C. Zhong, S. Yang, J. Huang, M.B. Cohen, P. Roy-Burman, Aberration in the expression of the retinoid receptor, $\mathrm{RXR} \alpha$, in prostate cancer, Cancer Biol. Ther. 2 (2003) 179-184, https://doi.org/10.4161/cbt.2.2.281.

[142] N. Ando, M. Shimizu, M. Okuno, R. Matsushima-Nishiwaki, H. Tsurumi, T. Tanaka, H. Moriwaki, Expression of retinoid X receptor $\alpha$ is decreased in $3^{\prime}$ methyl-4-dimethylaminoazobenzene-induced hepatocellular carcinoma in rats, Oncol. Rep. 18 (2007) 879-884, https://doi.org/10.3892/or.18.4.879.

[143] Y. Takiyama, N. Miyokawa, A. Sugawara, S. Kato, K. Ito, K. Sato, K. Oikawa, H. Kobayashi, S. Kimura, M. Tateno, Decreased expression of retinoid X receptor isoforms in human thyroid carcinomas, J. Clin. Endocrinol. Metab. 89 (2004) 5851-5861, https://doi.org/10.1210/jc.2003-032036.

[144] K. Yamazaki, M. Shimizu, M. Okuno, R. Matsushima-Nishiwaki, N. Kanemura, H. Araki, H. Tsurumi, S. Kojima, I.B. Weinstein, H. Moriwaki, Synergistic effects of RXR $\alpha$ and PPAR $\gamma$ ligands to inhibit growth in human colon cancer cells phosphorylated RXR $\alpha$ is a critical target for colon cancer management, Gut 56 (2007) 1557-1563, https://doi.org/10.1136/gut.2007.129858.

[145] R. Matsushima-Nishiwaki, M. Okuno, S. Adachi, T. Sano, K. Akita, H. Moriwaki, S. L. Friedman, S. Kojima, Phosphorylation of retinoid X receptor $\alpha$ at serine 260 impairs its metabolism and function in human hepatocellular carcinoma, Cancer Res. 61 (2001).

[146] G. Guo, X. Sun, C. Chen, S. Wu, P. Huang, Z. Li, M. Dean, Y. Huang, W. Jia, Q. Zhou, A. Tang, Z. Yang, X. Li, P. Song, X. Zhao, R. Ye, S. Zhang, Z. Lin, M. Qi, S. Wan, L. Xie, F. Fan, M.L. Nickerson, X. Zou, X. Hu, L. Xing, Z. Lv, H. Mei, S. Gao, C. Liang, Z. Gao, J. Lu, Y. Yu, C. Liu, L. Li, X. Fang, Z. Jiang, J. Yang, C. Li, X. Zhao, J. Chen, F. Zhang, Y. Lai, Z. Lin, F. Zhou, H. Chen, H.C. Chan, S. Tsang, D. Theodorescu, Y. Li, X. Zhang, J. Wang, H. Yang, Y. Gui, J. Wang, Z. Cai, Wholegenome and whole-exome sequencing of bladder cancer identifies frequent alterations in genes involved in sister chromatid cohesion and segregation, Nat. Genet. 45 (2013) 63-1459, https://doi.org/10.1038/ng.2798.

[147] J.N. Weinstein, R. Akbani, B.M. Broom, W. Wang, R.G.W. Verhaak, D. McConkey, et al., Comprehensive molecular characterization of urothelial bladder carcinoma, Nature 507 (2014) 22-315, https://doi.org/10.1038/nature12965.

[148] J.T. Goldstein, A.C. Berger, J. Shih, F.F. Duke, L. Furst, D.J. Kwiatkowski, A D. Cherniack, M. Meyerson, C.A. Strathdee, Genomic activation of PPARG reveals a candidate therapeutic axis in bladder cancer, Cancer Res. 77 (2017) 6987-6998, https://doi.org/10.1158/0008-5472.CAN-17-1701.

[149] R. Matsushima-Nishiwaki, Y. Shidoji, S. Nishiwaki, T. Yamada, H. Moriwaki, Y. Muto, Aberrant metabolism of retinoid X receptor proteins in human hepatocellular carcinoma, Mol. Cell. Endocrinol. 121 (1996) 179-190, https:// doi.org/10.1016/0303-7207(96)03863-4.

[150] K. Prüfer, C. Schröder, K. Hegyi, J. Barsony, Degradation of RXRs influences sensitivity of rat osteosarcoma cells to the antiproliferative effects of calcitriol, Mol. Endocrinol. 16 (2002) 961-976, https://doi.org/10.1210/mend.16.5.0821.

[151] H. Zhou, W. Liu, Y. Su, Z. Wei, J. Liu, S.K. Kolluri, H. Wu, Y. Cao, J. Chen, Y. Wu, T. Yan, X. Cao, W. Gao, A. Molotkov, F. Jiang, W.G. Li, B. Lin, H.P. Zhang, J. Yu, S.P. Luo, J.Z. Zeng, G. Duester, P.Q. Huang, X.K. Zhang, NSAID Sulindac and Its Analog Bind RXR $\alpha$ and Inhibit RXR $\alpha$-Dependent AKT Signaling, Cancer Cell 17 (2010) 560-573, https://doi.org/10.1016/j.ccr.2010.04.023.

[152] X. Ye, H. Wu, L. Sheng, Y. xin Liu, F. Ye, M. Wang, H. Zhou, Y. Su, X. kun Zhang, Oncogenic potential of truncated RXR $\alpha$ during colitis-associated colorectal tumorigenesis by promoting IL-6-STAT3 signaling, Nat. Commun. 10 (2019), https://doi.org/10.1038/s41467-019-09375-8.

[153] N.J. Bodsworth, M. Block, M. Bower, D. Donnell, R. Yocum, Phase III vehiclecontrolled, multi-centered study of topical alitretinoin gel $0.1 \%$ in cutaneous AIDS-related Kaposi's sarcoma, Am. J. Clin. Dermatol. 2 (2001) 77-87, https:// doi.org/10.2165/00128071-200102020-00004.

[154] F. Recchia, A. Lalli, M. Lombardo, S. De Filippis, G. Saggio, F. Fabbri, M. Rosselli, E. Capomolla, S. Rea, Ifosfamide, cisplatin, and 13-Cis retinoic acid for patients with advanced or recurrent squamous cell carcinoma of the head and neck: a phase I-II study, Cancer 92 (2001) 814-821, https://doi.org/10.1002/1097-0142 (20010815) $92: 4<814::$ AID-CNCR1387>3.0.CO $2-8$.

[155] L. Amoroso, R. Haupt, A. Garaventa, M. Ponzoni, Investigational drugs in phase II clinical trials for the treatment of neuroblastoma, Expert Opin. Investig. Drugs 26 (2017) 1281-1293, https://doi.org/10.1080/13543784.2017.1380625.

[156] M. Duvic, K. Hymes, P. Heald, D. Breneman, A.G. Martin, P. Myskowski, C. Crowley, R.C. Yocum, Bexarotene is effective and safe for treatment of refractory advanced-stage cutaneous t-cell lymphoma: multinational phase II-III trial results, J. Clin. Oncol. 19 (2001) 2456-2471, https://doi.org/10.1200/ ICO.2001.19.9.2456.

[157] T.W. Hermann, W.C. Yen, P. Tooker, B. Fan, K. Roegner, A. Negro-Vilar, W. W. Lamph, R.P. Bissonnette, The retinoid X receptor agonist bexarotene (Targretin) synergistically enhances the growth inhibitory activity of cytotoxic drugs in non-small cell lung cancer cells, Lung Cancer 50 (2005) 9-18, https:// doi.org/10.1016/j.lungcan.2005.05.008.

[158] W.C. Yen, M.R. Corpuz, R.Y. Prudente, T.A. Cooke, R.P. Bissonnette, A. NegroVilar, W.W. Lamph, A selective retinoid X receptor agonist bexarotene (Targretin) prevents and overcomes acquired paclitaxel (Taxol) resistance in human nonsmall cell lung cancer, Clin. Cancer Res. 10 (2004) 8656-8664, https://doi.org/ 10.1158/1078-0432.CCR-04-0979.

[159] G.R. Blumenschein, F.R. Khuri, J. Von Pawel, U. Gatzemeier, W.H. Miller, R. M. Jotte, J. Le Treut, S.L. Sun, J.K. Zhang, Z.E. Dziewanowska, A. Negro-Vilar, Phase III trial comparing carboplatin, paclitaxel, and bexarotene with carboplatin 
and paclitaxel in chemotherapy-naïve patients with advanced or metastatic nonsmall-cell lung cancer: SPIRIT II, J. Clin. Oncol. 26 (2008) 1879-1885, https:// doi.org/10.1200/JCO.2007.12.2689.

[160] R. Ramlau, P. Zatloukal, J. Jassem, P. Schwarzenberger, S.V. Orlov, M. Gottfried, J.R. Pereira, G. Temperley, R. Negro-Vilar, S. Rahal, J.K. Zhang, A. Negro-Vilar, Z E. Dziewanowska, Randomized phase III trial comparing bexarotene (L1069-49)/ cisplatin/ vinorelbine with cisplatin/vinorelbine in chemotherapy-naïve patients with advanced or metastatic non-small-cell lung cancer: SPIRIT I, J. Clin. Oncol. 26 (2008) 1886-1892, https://doi.org/10.1200/JCO.2007.12.2614.

[161] L. Altucci, A. Rossin, O. Hirsch, A. Nebbioso, D. Vitoux, E. Wilhelm, F. Guidez, M. De Simone, E.M. Schiavone, D. Grimwade, A. Zelent, H. De Thé,

H. Gronemeyer, Rexinoid-triggered differentiation and tumor-selective apoptosis of acute myeloid leukemia by protein kinase A-mediated desubordination of retinoid X receptor, Cancer Res. 65 (2005) 8754-8765, https://doi.org/10.1158/ 0008-5472.CAN-04-3569.

[162] J.S. Welch, H. Niu, G.L. Uy, P. Westervelt, C.N. Abboud, R. Vij, K.E. StockerlGoldstein, M. Jacoby, I. Pusic, M.A. Schroeder, J.F. Dipersio, A.F. Cashen, A phase I dose escalation study of oral bexarotene in combination with intravenous decitabine in patients with AML, Am. J. Hematol. 89 (2014), https://doi.org/ 10.1002/ajh.23735.

[163] P.V. Sanchez, S.T. Glantz, S. Scotland, M.T. Kasner, M. Carroll, Induced differentiation of acute myeloid leukemia cells by activation of retinoid $\mathrm{X}$ and liver X receptors, Leukemia 28 (2014) 749-760, https://doi.org/10.1038/ leu.2013.202.

[164] M. Shimizu, Y. Shirakami, K. Imai, K. Takai, H. Moriwaki, Acyclic retinoid in chemoprevention of hepatocellular carcinoma: targeting phosphorylated retinoid $\mathrm{X}$ receptor for prevention of liver carcinogenesis, J. Carcinog. 11 (2012), https:// doi.org/10.4103/1477-3163.100398.

[165] M. Honda, T. Yamashita, T. Yamashita, K. Arai, Y. Sakai, A. Sakai, M. Nakamura, E. Mizukoshi, S. Kaneko, Peretinoin, an acyclic retinoid, improves the hepatic gene signature of chronic hepatitis $\mathrm{C}$ following curative therapy of hepatocellular carcinoma, BMC Cancer 13 (2013), https://doi.org/10.1186/1471-2407-13-191.

[166] G.H. Wang, F.Q. Jiang, Y.H. Duan, Z P. Zeng, F Chen, Y. Dai, J.B. Chen, J.X. Liu, J. Liu, H. Zhou, H.F. Chen, J.Z. Zeng, Y. Su, X.S. Yao, X.K. Zhang, Targeting truncated retinoid X receptor- $\alpha$ by CF31 induces TNF- $\alpha$-dependent apoptosis, Cancer Res. 73 (2013) 307-318, https://doi.org/10.1158/0008-5472.CAN-122038.

[167] J. Zhu, R. Nasr, L. Pérès, F. Riaucoux-Lormière, N. Honoré, C. Berthier, D. Kamashev, J. Zhou, D. Vitoux, C. Lavau, H. de Thé, RXR is an essential component of the oncogenic PML/RARA complex in vivo, Cancer Cell 12 (2007) 23-35, https://doi.org/10.1016/j.ccr.2007.06.004.

[168] B.B. Zeisig, C. Kwok, A. Zelent, P. Shankaranarayanan, H. Gronemeyer, S. Dong, C.W.E. So, Recruitment of RXR by homotetrameric RAR $\alpha$ fusion proteins is essential for transformation, Cancer Cell 12 (2007) 36-51, https://doi.org/ 10.1016/j.ccr.2007.06.006.

[169] J.H.A. Martens, A.B. Brinkman, F. Simmer, K.J. Francoijs, A. Nebbioso, F. Ferrara L. Altucci, H.G. Stunnenberg, PML-RAR $\alpha /$ RXR alters the epigenetic landscape in acute promyelocytic leukemia, Cancer Cell 17 (2010) 173-185, https://doi.org/ 10.1016/j.ccr.2009.12.042.

[170] M. Kiss, Z. Czimmerer, G. Nagy, P. Bieniasz-Krzywiec, M. Ehling, A. Pap, S. Poliska, P. Boto, P. Tzerpos, A. Horvath, Z. Kolostyak, B. Daniel, I. Szatmari, M. Mazzone, L. Nagy, Retinoid X receptor suppresses a metastasis-promoting transcriptional program in myeloid cells via a ligand-insensitive mechanism, Proc. Natl. Acad. Sci. U. S. A. 114 (2017) 10725-10730, https://doi.org/ 10.1073/pnas.1700785114.

[171] M. Casanova-Acebes, M.P. Menéndez-Gutiérrez, J. Porcuna, D. Álvarez-Errico, Y. Lavin, A. García, S. Kobayashi, J. Le Berichel, V. Núñez, F. Were, D. JiménezCarretero, F. Sánchez-Cabo, M. Merad, M. Ricote, RXRs control serous macrophage neonatal expansion and identity and contribute to ovarian cancer progression, Nat. Commun. 11 (2020), https://doi.org/10.1038/s41467-02015371-0.

[172] M.P. Menendez-Gutierrez, T. Roszer, M. Ricote, Biology and therapeutic applications of peroxisome proliferator- activated receptors, Curr. Top. Med. Chem. 12 (2012) 548-584, https://doi.org/10.2174/156802612799436669.

[173] J.N. Feige, L. Gelman, L. Michalik, B. Desvergne, W. Wahli, From molecula action to physiological outputs: peroxisome proliferator-activated receptors are nuclear receptors at the crossroads of key cellular functions, Prog. Lipid Res. 45 (2006) 120-159, https://doi.org/10.1016/j.plipres.2005.12.002.

[174] I. Takada, M. Makishima, Peroxisome proliferator-activated receptor agonists and antagonists: a patent review (2014-present), Expert Opin. Ther. Pat. 30 (2020) 1-13, https://doi.org/10.1080/13543776.2020.1703952.

[175] H.S. Cheng, W.R. Tan, Z.S. Low, C. Marvalim, J.Y.H. Lee, N.S. Tan, Exploration and development of PPAR modulators in health and disease: an update of clinica evidence, Int. J. Mol. Sci. 20 (2019), https://doi.org/10.3390/ijms20205055.

[176] S.R. Pyper, N. Viswakarma, S. Yu, J.K. Reddy, PPARalpha: energy combustion, hypolipidemia, inflammation and cancer, Nucl. Recept. Signal. 8 (2010), https:// doi.org/10.1621/nrs.08002.

[177] L. Michalik, B. Desvergne, W. Wahli, Peroxisome-proliferator-activated receptors and cancers: complex stories, Nat. Rev. Cancer 4 (2004) 61-70, https://doi.org/ $10.1038 / \mathrm{nrc1} 254$.

[178] J.M. Peters, Y.M. Shah, F.J. Gonzalez, The role of peroxisome proliferatoractivated receptors in carcinogenesis and chemoprevention, Nat. Rev. Cancer 12 (2012) 181-195, https://doi.org/10.1038/nrc3214.

[179] S.S. Lee, T. Pineau, J. Drago, E.J. Lee, J.W. Owens, D.L. Kroetz, P.M. FernandezSalguero, H. Westphal, F.J. Gonzalez, Targeted disruption of the alpha isoform of the peroxisome proliferator-activated receptor gene in mice results in abolishment of the pleiotropic effects of peroxisome proliferators, Mol. Cell. Biol. 15 (1995) 3012-3022, https://doi.org/10.1128/mcb.15.6.3012.

[180] J. Ashby, A. Brady, C.R. Elcombe, B.M. Elliott, J. Ishmael, J. Odum, J. D. Tugwood, S. Kettle, I.F.H. Purchase, Mechanistically-based human hazard assessment of peroxisome proliferator-induced hepatocarcinogenesis, Hum. Exp. Toxicol. 13 (1994), https://doi.org/10.1177/096032719401300201.

[181] S.A. Saha, L.G. Kizhakepunnur, A. Bahekar, R.R. Arora, The role of fibrates in the prevention of cardiovascular disease-a pooled meta-analysis of long-term randomized placebo-controlled clinical trials, Am. Heart J. 154 (2007) 943-953, https://doi.org/10.1016/j.ahj.2007.07.011.

[182] J.C. Corton, J.M. Peters, J.E. Klaunig, The PPAR $\alpha$-dependent rodent liver tumor response is not relevant to humans: addressing misconceptions, Arch. Toxicol. 92 (2018) 83-119, https://doi.org/10.1007/s00204-017-2094-7.

[183] Y. Xi, Y. Zhang, S. Zhu, Y. Luo, P. Xu, Z. Huang, PPAR-mediated toxicology and applied pharmacology, Cells 9 (2020) 352, https://doi.org/10.3390/ cells9020352.

[184] K. Tachibana, D. Yamasaki, K. Ishimoto, T. Doi, The role of PPARs in cancer, PPAR Res. 2008 (2008), https://doi.org/10.1155/2008/102737.

[185] K. Morimura, C. Cheung, J.M. Ward, J.K. Reddy, F.J. Gonzalez, Differential susceptibility of mice humanized for peroxisome proliferator-activated receptor a to Wy-14,643-induced liver tumorigenesis, (n.d.). https://doi.org/10.1093/carc in/bgi329.

[186] Q. Yang, T. Nagano, Y. Shah, C. Cheung, S. Ito, F.J. Gonzalez, The PPARaHumanized mouse: a model to investigate species differences in liver toxicity mediated by PPARa, Toxicol. Sci. 101 (2008) 132-139, https://doi.org/10.1093/ toxsci/kfm206.

[187] Y.M. Shah, K. Morimura, Q. Yang, T. Tanabe, M. Takagi, F.J. Gonzalez, Peroxisome proliferator-activated receptor $\alpha$ regulates a MicroRNA-mediated signaling cascade responsible for hepatocellular proliferation, Mol. Cell. Biol. 27 (2007) 4238-4247, https://doi.org/10.1128/mcb.00317-07.

[188] S.P. Lakshmi, A.T. Reddy, A. Banno, R.C. Reddy, PPAR Agonists for the Prevention and Treatment of Lung Cancer, 2017, https://doi.org/10.1155/2017/ 8252796.

[189] L. Wu, W. Wang, M. Dai, H. Li, C. Chen, D. Wang, PPAR $\alpha$ ligand, AVE8134, and cyclooxygenase inhibitor therapy synergistically suppress lung cancer growth and metastasis, BMC Cancer 19 (2019), https://doi.org/10.1186/s12885-019-6379-5.

[190] A. Fidoamore, L. Cristiano, C. Laezza, R. Galzio, E. Benedetti, B. Cinque, A. Antonosante, M. d'Angelo, V. Castelli, M.G. Cifone, R. Ippoliti, A. Giordano, A. Cimini, Energy metabolism in glioblastoma stem cells: PPAR $\alpha$ a metabolic adaptor to intratumoral microenvironment, Oncotarget 8 (2017) 108430-108450, https://doi.org/10.18632/oncotarget.19086.

[191] A. Pozzi, M.R. Ibanez, A.E. Gatica, S. Yang, S. Wei, S. Mei, J.R. Falck, J. H. Capdevila, Peroxisomal proliferator-activated receptor- $\alpha$-dependent inhibition of endothelial cell proliferation and tumorigenesis, J. Biol. Chem. 282 (2007) 17685-17695, https://doi.org/10.1074/jbc.M701429200.

[192] D. Panigrahy, A. Kaipainen, S. Huang, C.E. Butterfield, C.M. Barnés, M. Fannon, A.M. Laforme, D.M. Chaponis, J. Folkman, M.W. Kieran, PPAR $\alpha$ agonist fenofibrate suppresses tumor growth through direct and indirect angiogenesis inhibition, Proc. Natl. Acad. Sci. U. S. A. 105 (2008) 985-990, https://doi.org/ 10.1073/pnas.0711281105.

[193] M. Ricote, C.K. Glass, PPARs and molecular mechanisms of transrepression, Biochim. Biophys. Acta - Mol. Cell Biol. Lipids 1771 (2007) 926-935, https://doi. org/10.1016/j.bbalip.2007.02.013.

[194] T. Aoyama, J.M. Peters, N. Iritani, T. Nakajima, K. Furihata, T. Hashimoto, F. J. Gonzalez, Altered constitutive expression of fatty acid-metabolizing enzymes in mice lacking the peroxisome proliferator-activated receptor $\alpha$ (PPAR $\alpha$ ), J. Biol. Chem. 273 (1998) 5678-5684, https://doi.org/10.1074/jbc.273.10.5678.

[195] S. Kersten, S. Mandard, P. Escher, F.J. Gonzalez, S. Tafuri, B. Desvergne, W. Wahli, The peroxisome proliferator-activated receptor $\alpha$ regulates amino acid metabolism, FASEB J. 15 (2001) 1971-1978, https://doi.org/10.1096/fj.01$0147 \mathrm{com}$

[196] Y. Luo, C. Xie, C.N. Brocker, J. Fan, X. Wu, L. Feng, Q. Wang, J. Zhao, D. Lu, M. Tandon, M. Cam, K.W. Krausz, W. Liu, F.J. Gonzalez, Intestinal PPAR $\alpha$ protects against colon carcinogenesis via regulation of methyltransferases DNMT1 and PRMT6, Gastroenterology 157 (2019) 744-759, https://doi.org/10.1053/j. gastro.2019.05.057, e4.

[197] X. Zuo, W. Xu, M. Xu, R. Tian, M.J. Moussalli, F. Mao, X. Zheng, J. Wang, J. S. Morris, M. Gagea, C. Eng, S. Kopetz, D.M. Maru, A. Rashid, R. Broaddus, D. Wei, M.-C. Hung, A.K. Sood, I. Shureiqi, Metastasis regulation by PPARD expression in cancer cells, JCI Insight 2 (2017), https://doi.org/10.1172/jci. insight.91419.

[198] M. Yoshinaga, K. Taki, S. Somada, Y. Sakiyama, N. Kubo, T. Kaku, S. Tsuruta, T. Kusumoto, H. Sakai, K. Nakamura, R. Takayanagi, Y. Muto, The expression of both peroxisome proliferator-activated receptor delta and cyclooxygenase-2 in tissues is associated with poor prognosis in colorectal cancer patients, Dig. Dis Sci. 56 (2011) 1194-1200, https://doi.org/10.1007/s10620-010-1389-9.

[199] O. Takayama, H. Yamamoto, B. Damdinsuren, Y. Sugita, C.Y. Ngan, X. Xu, T. Tsujino, I. Takemasa, M. Ikeda, M. Sekimoto, N. Matsuura, M. Monden, Expression of PPAR $\delta$ in multistage carcinogenesis of the colorectum: implications of malignant cancer morphology, Br. J. Cancer 95 (2006) 889-895, https://doi. org/10.1038/sj.bjc.6603343.

[200] A. Abdollahi, C. Schwager, J. Kleeff, I. Esposito, S. Domhan, P. Peschke, K. Hauser, P. Hahnfeldt, L. Hlatky, J. Debus, J.M. Peters, H. Friess, J. Folkman, P. E. Huber, Transcriptional network governing the angiogenic switch in human pancreatic cancer, Proc. Natl. Acad. Sci. U. S. A. 104 (2007) 12890-12895, https://doi.org/10.1073/pnas.0705505104. 
[201] T.V. Pedchenko, A.L. Gonzalez, D.Z. Wang, R.N. DuBois, P.P. Massion, Peroxisome proliferator-activated receptor $\beta / \delta$ expression and activation in lung cancer, Am. J. Respir. Cell Mol. Biol. 39 (2008) 689-696, https://doi.org/ 10.1165/rcmb.2007-04260C.

[202] R. Müller, PPAR $\beta / \delta$ in human cancer, Biochimie 136 (2017) 90-99, https://doi. org/10.1016/j.biochi.2016.10.019.

[203] X. Zuo, M. Xu, J. Yu, Y. Wu, M.J. Moussalli, G.C. Manyam, S. Il Lee, S. Liang, M. Gagea, J.S. Morris, R.R. Broaddus, I. Shureiqi, Potentiation of Colon Cancer Susceptibility in Mice by Colonic Epithelial PPAr- $\delta / \beta$ Overexpression, 2014, p. 106, https://doi.org/10.1093/jnci/dju052.

[204] D. Wang, L. Fu, J. Wei, Y. Xiong, R.N. DuBois, PPARD mediates the effect of dietary fat in promoting colorectal cancer metastasis, Cancer Res. 79 (2019) 4480-4490, https://doi.org/10.1158/0008-5472.CAN-19-0384.

[205] S. Beyaz, M.D. Mana, J. Roper, D. Kedrin, A. Saadatpour, S.J. Hong, K.E. Bauer Rowe, M.E. Xifaras, A. Akkad, E. Arias, L. Pinello, Y. Katz, S. Shinagare, M. AbuRemaileh, M.M. Mihaylova, D.W. Lamming, R. Dogum, G. Guo, G.W. Bell, M. Selig, G.P. Nielsen, N. Gupta, C.R. Ferrone, V. Deshpande, G.C. Yuan, S H. Orkin, D.M. Sabatini, Ö.H. Yilmaz, High-fat diet enhances stemness and tumorigenicity of intestinal progenitors, Nature 531 (2016) 53-58, https://doi. org/10.1038/nature17173.

[206] L. Yang, H. Zhang, Z.G. Zhou, H. Yan, G. Adell, X.F. Sun, Biological function and prognostic significance of peroxisome proliferator-activated receptor $\delta$ in rectal cancer, Clin. Cancer Res. 17 (2011) 3760-3770, https://doi.org/10.1158/10780432.CCR-10-2779.

[207] N. Martín-Martín, A. Zabala-Letona, S. Fernandez-Ruiz, L. Arreal, L. Camacho, M. Castillo-Martin, A.R. Cortazar, V. Torrano, I. Astobiza, P. Zuñiga-García, A. Ugalde-Olano, A. Loizaga-Iriarte, M. Unda, L. Valcarcel-Jim enez, A. Arruabarrena-Aristorena, M. Piva, P. Sanchez-Mosquera, A.M. Aransay, A. Gomez-Muñoz, R. Barrio, J.D. Sutherland, A. Carracedo, PPARd elicits ligandindependent repression of trefoil factor family to limit prostate cancer growth, Cancer Res. 78 (2018) 399-409, https://doi.org/10.1158/0008-5472.CAN-170908.

[208] B. Zhu, R. Bai, M.J. Kennett, B.H. Kang, F.J. Gonzalez, J.M. Peters, Chemoprevention of chemically induced skin tumorigenesis by ligand activation of peroxisome proliferator-activated receptor- $\beta / \delta$ and inhibition of cyclooxygenase 2, Mol. Cancer Ther. 9 (2010) 3267-3277, https://doi.org/ 10.1158/1535-7163.MCT-10-0820.

[209] M.T. Bility, M.K. Devlin-Durante, N. Blazanin, A.B. Glick, J.M. Ward, H. Kang, M. J. Kennett, F.J. Gonzalez, J.M. Peters, Ligand activation of peroxisome proliferator-activated receptor $\mathrm{b} / \mathrm{d}$ (PPARb/d) inhibits chemically induced skin tumorigenesis, Carcinogenesis 29 (2008) 2406-2414, https://doi.org/10.1093/ carcin/bgn219.

[210] F.S. Harman, C.J. Nicol, H.E. Marin, J.M. Ward, F.J. Gonzalez, J.M. Peters, Peroxisome proliferator-activated receptor- $\delta$ attenuates colon carcinogenesis, Nat. Med. 10 (2004) 481-483, https://doi.org/10.1038/nm1026.

[211] X. Zuo, Z. Peng, M.J. Moussalli, J.S. Morris, R.R. Broaddus, S.M. Fischer, I. Shureiqi, Targeted genetic disruption of peroxisome proliferator-activated receptor- $\delta$ and colonic tumorigenesis, J. Natl. Cancer Inst. 101 (2009) 7-762, https://doi.org/10.1093/jnci/djp078.

[212] D. Wang, H. Wang, Y. Guo, W. Ning, S. Katkuri, W. Wahli, B. Desvergne, S.K. Dey, R.N. DuBois, Crosstalk between peroxisome proliferator-activated receptor $\delta$ an VEGF stimulates cancer progression, Proc. Natl. Acad. Sci. U. S. A. 103 (2006) 19069-19074, https://doi.org/10.1073/pnas.0607948103.

[213] S. Müller-Brüsselbach, M. Kömhoff, M. Rieck, W. Meissner, K. Kaddatz, J. Adamkiewicz, B. Keil, K.J. Klose, R. Moll, A.D. Burdick, J.M. Peters, R. Müller, Deregulation of tumor angiogenesis and blockade of tumor growth in PPAR $\beta$ deficient mice, EMBO J. 26 (2007) 98-3686, https://doi.org/10.1038/sj. emboj.7601803.

[214] M. Ghosh, Y. Ai, K. Narko, Z. Wang, J.M. Peters, T. Hla, PPARס is pro-tumorigenic in a mouse model of COX-2-induced mammary cancer, Prostaglandins Other Lipid Mediat. 88 (2009) 97-100, https://doi.org/10.1016/j. prostaglandins.2008.11.004.

[215] S.A. Ham, T. Yoo, J.S. Hwang, E.S. Kang, W.J. Lee, K.S. Paek, C. Park, J.-H. Kim, J.T. Do, D.-S. Lim, H.G. Seo, Ligand-activated PPAR $\delta$ modulates the migration and invasion of melanoma cells by regulating Snail expression, Am. J. Cancer Res. 4 (2014) 674.

[216] R. Vigneri, L. Sciacca, P. Vigneri, Rethinking the relationship between insulin and cancer, Trends Endocrinol. Metab. 31 (2020), https://doi.org/10.1016/j. tem.2020.05.004.

[217] A. Bundscherer, A. Reichle, C. Hafner, S. Meyer, T. Vogt, Targeting the tumo stroma with peroxisome proliferator activated receptor (PPAR) agonists, Anticancer Agents Med. Chem. 9 (2012) 21-816, https://doi.org/10.2174/ 187152009789056912

[218] A. Vallée, Y. Lecarpentier, J.-N. Vallée, Targeting the canonical WNT/ $\beta$-catenin pathway in cancer treatment using non-steroidal anti-inflammatory drugs, Cells 8 (2019) 726, https://doi.org/10.3390/cells8070726.

[219] E. Fröhlich, R. Wahl, Chemotherapy and chemoprevention by thiazolidinediones, Biomed Res. Int. 2015 (2015) 845340, https://doi.org/10.1155/2015/845340.

[220] G.T. Robbins, D. Nie, PPAR gamma, bioactive lipids, and cancer progression, Front. Biosci. 17 (2012) 1816-1834, https://doi.org/10.2741/4021.

[221] R.E. Soccio, E.R. Chen, M.A. Lazar, Thiazolidinediones and the promise of insulin sensitization in type 2 diabetes, Cell Metab. 20 (2014) 91-573, https://doi.org/ 10.1016/j.cmet.2014.08.005.

[222] A. Ferrara, J.D. Lewis, C.P. Quesenberry, T. Peng, B.L. Strom, S.K. Van Den Eeden, S.F. Ehrlich, L.A. Habel, Cohort study of pioglitazone and cancer incidence in patients with diabetes, Diabetes Care 34 (2011) 923-929, https://doi.org/ 10.2337/dc10-1067.

[223] B. Wang, P. Tontonoz, Liver X receptors in lipid signalling and membrane homeostasis, Nat. Rev. Endocrinol. 14 (2018) 452-463, https://doi.org/10.1038/ s41574-018-0037-x.

[224] C.P. Chuu, H.P. Lin, Antiproliferative effect of LXR agonists T0901317 and 22(R)hydroxycholesterol on multiple human cancer cell lines, Anticancer Res. 30 (2010) 3643-3648.

[225] G. Lo Sasso, F. Bovenga, S. Murzilli, L. Salvatore, G. Di Tullio, N. Martelli, A. D'Orazio, S. Rainaldi, M. Vacca, A. Mangia, G. Palasciano, A. Moschetta, Liver $\mathrm{X}$ receptors inhibit proliferation of human colorectal cancer cells and growth of intestinal tumors in mice, Gastroenterology 144 (2013) 1497-1507, https://doi. org/10.1053/j.gastro.2013.02.005, e13.

[226] A.J.C. Pommier, G. Alves, E. Viennois, S. Bernard, Y. Communal, B. Sion, G. Marceau, C. Damon, K. Mouzat, F. Caira, S. Baron, J.M.A. Lobaccaro, Liver X Receptor activation downregulates AKT survival signaling in lipid rafts and induces apoptosis of prostate cancer cells, Oncogene 29 (2010) 2712-2723, https://doi.org/10.1038/onc.2010.30.

[227] L.L. Vedin, J.A. Gustafsson, K.R. Steffensen, The oxysterol receptors lxr $\alpha$ and $\operatorname{lxr} \beta$ suppress proliferation in the colon, Mol. Carcinog. 52 (2013) 835-844, https:// doi.org/10.1002/mc.21924.

[228] W. Fu, J. Yao, Y. Huang, Q. Li, W. Li, Z. Chen, F. He, Z. Zhou, J. Yan, LXR agonist regulates the carcinogenesis of PCa via the SOCS3 pathway, Cell. Physiol. Biochem. 33 (2014) 195-204, https://doi.org/10.1159/000356662.

[229] V. Derangère, A. Chevriaux, F. Courtaut, M. Bruchard, H. Berger, F. Chalmin, S. Z. Causse, E. Limagne, F. Végran, S. Ladoire, B. Simon, W. Boireau, A. Hichami, L. Apetoh, G. Mignot, F. Ghiringhelli, C. Rébé, Liver X receptor $\beta$ activation induces pyroptosis of human and murine colon cancer cells, Cell Death Differ. 21 (2014) 1914-1924, https://doi.org/10.1038/cdd.2014.117.

[230] W. Zhang, H. Jiang, J. Zhang, Y. Zhang, A. Liu, Y. Zhao, X. Zhu, Z. Lin, X. Yuan, Liver $\mathrm{X}$ receptor activation induces apoptosis of melanoma cell through caspase pathway, Cancer Cell Int. 14 (2014), https://doi.org/10.1186/1475-2867-14-16.

[231] G.R. Villa, J.J. Hulce, C. Zanca, J. Bi, S. Ikegami, G.L. Cahill, Y. Gu, K.M. Lum, K. Masui, H. Yang, X. Rong, C. Hong, K.M. Turner, F. Liu, G.C. Hon, D. Jenkins, M. Martini, A.M. Armando, O. Quehenberger, T.F. Cloughesy, F.B. Furnari, W. K. Cavenee, P. Tontonoz, T.C. Gahman, A.K. Shiau, B.F. Cravatt, P.S. Mischel, An XR-cholesterol axis creates a metabolic co-dependency for brain cancers, Cancer Cell 30 (2016) 683-693, https://doi.org/10.1016/j.ccell.2016.09.008.

[232] C. Hu, D. Liu, Y. Zhang, G. Lou, G. Huang, B. Chen, X. Shen, M. Gao, W. Gong, P. Zhou, S. Dai, Y. Zeng, F. He, LXR $\alpha$-mediated downregulation of FOXM1 suppresses the proliferation of hepatocellular carcinoma cells, Oncogene 33 (2014) 2888-2897, https://doi.org/10.1038/onc.2013.250.

[233] L.-L. Vedin, S.A. Lewandowski, P. Parini, J.-A. Gustafsson, K.R. Steffensen, The oxysterol receptor LXR inhibits proliferation of human breast cancer cells, Carcinogenesis 30 (2009) 575-579, https://doi.org/10.1093/carcin/bgp029.

[234] K.H. Kim, G.Y. Lee, J.I. Kim, M. Ham, J. Won Lee, J.B. Kim, Inhibitory effect of LXR activation on cell proliferation and cell cycle progression through lipogenic activity, J. Lipid Res. 51 (2010) 3425-3433, https://doi.org/10.1194/jlr. M007989.

[235] H. Xiong, Y. Zhang, S. Chen, Z. Ni, J. He, X. Li, B. Li, K. Zhao, F. Yang, Y. Zeng, B. Chen, F. He, Induction of SOCS3 by liver X receptor suppresses the proliferation of hepatocellular carcinoma cells, Oncotarget 8 (2017) 64083-64094, https:// doi.org/10.18632/oncotarget.19321.

[236] J. Fukuchi, J.M. Kokontis, R.A. Hiipakka, C.-P. Chuu, S. Liao, Antiproliferative effect of liver X receptor agonists on LNCaP human prostate cancer cells, Cancer Res. 64 (2004) 7686-7689, https://doi.org/10.1158/0008-5472.CAN-04-2332.

[237] N.R. Candelaria, S. Addanki, J. Zheng, T. Nguyen-Vu, H. Karaboga, P. Dey, C. Gabbi, L.L. Vedin, K. Liu, W. Wu, P.K. Jonsson, J.Z. Lin, F. Su, L.R. Bollu, S. E. Hodges, A.L. McElhany, M.A. Issazadeh, W.E. Fisher, M.M. Ittmann, K. R. Steffensen, J.Å. Gustafsson, C.Y. Lin, Antiproliferative effects and mechanisms of liver X receptor ligands in pancreatic ductal adenocarcinoma cells, PLoS One 9 (2014), https://doi.org/10.1371/journal.pone.0106289.

[238] K. Youlin, Z. Li, H. Weiyang, K. Jian, L. Siming, G. Xin, Liver X receptor activation inhibits PC-3 prostate cancer cells via the beta-catenin pathway, Pathol. Res. Pract. 213 (2017) 267-270, https://doi.org/10.1016/j.prp.2016.04.013.

[239] A. El Roz, J.M. Bard, J.M. Huvelin, H. Nazih, LXR agonists and ABCG1-dependent cholesterol efflux in MCF-7 breast cancer cells: relation to proliferation and apoptosis, Anticancer Res. 32 (2012) 3007-3013.

[240] G. Segala, M. David, P. De Medina, M.C. Poirot, N. Serhan, F. Vergez, A. Mougel, E. Saland, K. Carayon, J. Leignadier, N. Caron, M. Voisin, J. Cherier, L. Ligat, F. Lopez, E. Noguer, A. Rives, B. Payré, T. Al Saati, A. Lamaziere, G. Despres, J. M. Lobaccaro, S. Baron, C. Demur, F. De Toni, C. Larrue, H. Boutzen, F. Thomas, J.E. Sarry, M. Tosolini, D. Picard, M. Record, C. Récher, M. Poirot, S. SilventePoirot, Dendrogenin A drives LXR to trigger lethal autophagy in cancers, Nat. Commun. 8 (2017) 1-17, https://doi.org/10.1038/s41467-017-01948-9.

[241] P. De Medina, M.R. Paillasse, G. Segala, M. Voisin, L. Mhamdi, F. Dalenc, M. Lacroix-Triki, T. Filleron, F. Pont, T. Al Saati, C. Morisseau, B.D. Hammock, S. Silvente-Poirot, M. Poirot, Dendrogenin A arises from cholesterol and histamine metabolism and shows cell differentiation and anti-tumour properties, Nat. Commun. 4 (2013), https://doi.org/10.1038/ncomms2835.

[242] M. Bauriaud-Mallet, L. Vija-Racaru, S. Brillouet, A. Mallinger, P. de Medina, A. Rives, B. Payre, M. Poirot, F. Courbon, S. Silvente-Poirot, The cholesterolderived metabolite dendrogenin A functionally reprograms breast adenocarcinoma and undifferentiated thyroid cancer cells, J. Steroid Biochem. Mol. Biol. 192 (2019) 105390, https://doi.org/10.1016/j.jsbmb.2019.105390. 
[243] C.A. Flaveny, K. Griffett, B.E.D.M. El-Gendy, M. Kazantzis, M. Sengupta, A. L. Amelio, A. Chatterjee, J. Walker, L.A. Solt, T.M. Kamenecka, T.P. Burris, Broad anti-tumor activity of a small molecule that selectively targets the warburg effect and lipogenesis, Cancer Cell 28 (2015) 42-56, https://doi.org/10.1016/j. ccell.2015.05.007.

[244] N. Pencheva, C.G. Buss, J. Posada, T. Merghoub, S.F. Tavazoie, Broad-spectrum therapeutic suppression of metastatic melanoma through nuclear hormone receptor activation, Cell 156 (2014) 986-1001, https://doi.org/10.1016/j. cell.2014.01.038.

[245] A. Noghero, A. Perino, G. Seano, E. Saglio, G. Lo Sasso, F. Veglio, L. Primo, E. Hirsch, F. Bussolino, F. Morello, Liver X receptor activation reduces angiogenesis by impairing lipid raft localization and signaling of vascular endothelial growth factor receptor-2, Arterioscler. Thromb. Vasc. Biol. 32 (2012) 2280-2288, https://doi.org/10.1161/ATVBAHA.112.250621.

[246] A. El Roz, J.M. Bard, S. Valin, J.M. Huvelin, H. Nazih, Macrophage apolipoprotein e and proliferation of MCF-7 breast cancer cells: role of LXR, Anticancer Res. 33 (2013) 3783-3790.

[247] M.F. Tavazoie, I. Pollack, R. Tanqueco, B.N. Ostendorf, B.S. Reis, F.C. Gonsalves, I. Kurth, C. Andreu-Agullo, M.L. Derbyshire, J. Posada, S. Takeda, K. N. Tafreshian, E. Rowinsky, M. Szarek, R.J. Waltzman, E.A. Mcmillan, C. Zhao, M. Mita, A. Mita, B. Chmielowski, M.A. Postow, A. Ribas, D. Mucida, S. F. Tavazoie, LXR/ApoE activation restricts innate immune suppression in cancer, Cell 172 (2018) 825-840, https://doi.org/10.1016/j.cell.2017.12.026, e18.

[248] A Study of RGX-104 in Patients With Advanced Solid Malignancies and Lymphoma - Full Text View - ClinicalTrials.gov, (n.d.). https://clinicaltrials.gov/c t2/show/NCT02922764. (Accessed 18 June 2020).

[249] H. Long, X. Guo, S. Qiao, Q. Huang, Tumor LXR expression is a prognostic marker for patients with hepatocellular carcinoma, Pathol. Oncol. Res. 24 (2018) 339-344, https://doi.org/10.1007/s12253-017-0249-8.

[250] E.J. Villablanca, L. Raccosta, D. Zhou, R. Fontana, D. Maggioni, A. Negro, F. Sanvito, M. Ponzoni, B. Valentinis, M. Bregni, A. Prinetti, K.R. Steffensen, S. Sonnino, J. Gustafsson, C. Doglioni, C. Bordignon, C. Traversari, V. Russo, Tumor - mediated liver $\mathrm{X}$ receptor - $\alpha$ activation inhibits CC chemokine receptor 7 expression on dendritic cells and dampens antitumor responses, Nat. Med. 16 (2009) 98-105, https://doi.org/10.1038/nm.2074.

[251] S. Beceiro, A. Pap, Z. Czimmerer, T. Sallam, J.A. Guillén, G. Gallardo, C. Hong, N. A-Gonzalez, C. Tabraue, M. Diaz, F. Lopez, J. Matalonga, A.F. Valledor, P. Dominguez, C. Ardavin, C. Delgado-Martin, S. Partida-Sanchez, J.L. Rodriguez-
Fernandez, L. Nagy, P. Tontonoz, A. Castrillo, Liver X receptor nuclear receptors are transcriptional regulators of dendritic cell chemotaxis, Mol. Cell. Biol. 38 (2018), https://doi.org/10.1128/mcb.00534-17 e00534-17.

[252] J.E. Feig, I. Pineda-Torra, M. Sanson, M.N. Bradley, Y. Vengrenyuk, D. Bogunovic, E.L. Gautier, D. Rubinstein, C. Hong, J. Liu, C. Wu, N. van Rooijen, N. Bhardwaj, M. Garabedian, P. Tontonoz, E.A. Fisher, LXR promotes the maximal egress of monocyte-derived cells from mouse aortic plaques during atherosclerosis regression, J. Clin. Invest. 120 (2010) 4415-4424, https://doi.org/10.1172/ JCI38911.

[253] P. Goossens, J. Rodriguez-Vita, A. Etzerodt, M. Masse, O. Rastoin, V. Gouirand, T. Ulas, O. Papantonopoulou, M. Van Eck, N. Auphan-Anezin, M. Bebien, C. Verthuy, T.P. Vu Manh, M. Turner, M. Dalod, J.L. Schultze, T. Lawrence, Membrane cholesterol efflux drives tumor-associated macrophage reprogramming and tumor progression, Cell Metab. 29 (2019) 1376-1389, https://doi.org/10.1016/j.cmet.2019.02.016, e4.

[254] T. Tanaka, Preclinical cancer chemoprevention studies using animal model of inflammation-associated colorectal carcinogenesis, Cancers (Basel) 4 (2012) 673-700, https://doi.org/10.3390/cancers4030673.

[255] F. Lalloyer, T.A. Pedersen, B. Gross, S. Lestavel, S. Yous, E. Vallez, J.Å. Gustafsson, S. Mandrup, C. Fiévet, B. Staels, A. Tailleux, Rexinoid bexarotene modulates triglyceride but not cholesterol metabolism via gene-specific permissivity of the RXR/LXR heterodimer in the liver, Arterioscler. Thromb. Vasc. Biol. 29 (2009) 1488-1495, https://doi.org/10.1161/ATVBAHA.109.189506.

[256] J.R. Schultz, H. Tu, A. Luk, J.J. Repa, J.C. Medina, L. Li, S. Schwendner, S. Wang, M. Thoolen, D.J. Mangelsdorf, K.D. Lustig, B. Shan, Role of LXRs in control of lipogenesis, Genes Dev. 14 (2000) 2831-2838.

[257] E.F. Garner, L.L. Stafman, A.P. Williams, J.M. Aye, C. Goolsby, V.R. Atigadda, B. P. Moore, L. Nan, J.E. Stewart, A.B. Hjelmeland, G.K. Friedman, E.A. Beierle, UAB30, a novel RXR agonist, decreases tumorigenesis and leptomeningeal disease in group 3 medulloblastoma patient-derived xenografts, J. Neurooncol. 140 (2018) 209-224, https://doi.org/10.1007/s11060-018-2950-1.

[258] X. Yu, P. Yi, R.A. Hamilton, H. Shen, M. Chen, C. Foulds, M. Mancini, S. Ludtke, Z. Wang, B. O'Malley, Structural insights of transcriptionally active, full-length androgen receptor coactivator complexes, SSRN Electron. J. (2020), https://doi. org/10.2139/ssrn.3578148.

[259] D. Hanahan, R.A. Weinberg, Hallmarks of cancer: the next generation, Cell 144 (2011) 646-674, https://doi.org/10.1016/j.cell.2011.02.013. 